\title{
Revision of the genus Glyptoxanthus A. Milne-Edwards, 1879, and establishment of Glyptoxanthinae nov. subfam. (Crustacea: Decapoda: Brachyura: Xanthidae)
}

\author{
JOSE CHRISTOPHER E. MENDOZA ${ }^{1,3}$ \& DANIÈLE GUINOT ${ }^{2}$ \\ ${ }^{1}$ Department of Biological Sciences, National University of Singapore, 14 Science Drive 4, 117543, Singapore. \\ E-mail: dbsjose@nus.edu.sg \\ ${ }^{2}$ Muséum National d'Histoire Naturelle, Département Milieux et peuplements aquatiques, CP 53, 61 rue Buffon, F-75231 Paris cedex \\ 05, France. E-mail: guinot@mnhn.fr \\ ${ }^{3}$ Corresponding author
}

\begin{abstract}
The xanthid genus Glyptoxanthus A. Milne-Edwards, 1879, known from the tropical eastern Pacific, western and eastern Atlantic, and the Red Sea, is revised as part of an ongoing revision of the subfamily Euxanthinae Alcock, 1898. Analysis of morphological characters shows that Glyptoxanthus must be excluded from the subfamily Euxanthinae and placed in a distinct subfamily, Glyptoxanthinae nov. subfam. The new subfamily has affinities to Euxanthinae, Actaeinae Alcock, 1898, and Zalasiinae Serène, 1968, but it is distinguished from these by a suite of characters in the thoracic sternum, third maxillipeds, epistome, chelipeds, and male abdomen and gonopods. All the included species are re-diagnosed, with additional comments and updates on their biology and distribution. In an effort to stabilize the taxonomy of the genus and some of its species, neotypes were selected for G. erosus (Stimpson, 1859) (type species), G. labyrinthicus (Stimpson, 1860), and G. meandricus (Lockington, 1877). A key to the genus is included.
\end{abstract}

Key words: Xanthoidea, Xanthidae, Actaeinae, Euxanthinae, Zalasiinae, systematics, carapace sculpture, thoracic sternum, coaptation

\section{Introduction}

The genus Glyptoxanthus was established by A. Milne-Edwards (1879) to receive six species from the eastern and western coasts of the Americas and the western coast of Africa. The six species had been placed under different genera at that time: Cancer vermiculatus Lamarck, 1818, Actaea erosa Stimpson, 1859, Actaea labyrinthica Stimpson, 1860, Xantho corrosus A. Milne-Edwards, 1869, Actaea angolensis Brito Capello, 1866, and Actaea cavernosa A. Milne-Edwards, 1878. All these species were characterized by the prominent vermiculate sculpturing on the surface of the carapace and pereopods. A seventh species, Actaea meandrica Lockington, 1877, described from the Gulf of California, was missed by A. Milne-Edwards (1879). An eighth species, Actaea meandrina Klunzinger (1913), was described from the Red Sea. Rathbun (1930) subsequently selected A. erosa as the type species of the genus. She also considered A. meandrica Lockington, 1877, a junior synonym of Glyptoxanthus labyrinthicus (Stimpson, 1860). The ninth, and last, species to be described was G. hancocki Garth, 1939, from the Galápagos Islands. Some (Odhner, 1925; Monod 1956) did not recognize Glyptoxanthus as a valid genus, considering it as a junior synonym or subgenus of Actaea De Haan, 1833. Guinot (1967, 1979), however, citing earlier authors, particularly A. Milne-Edwards (1879), Rathbun (1930) and Garth (1939, 1946), considered Glyptoxanthus to be a distinct and homogenous grouping apart from Actaea, citing its many unique morphological features. She went on further to include Glyptoxanthus in the subfamily Euxanthinae Alcock, 1898, citing morphological similarities with the core genera Euxanthus Dana, 1851, and Hypocolpus Rathbun, 1897 (i.e., condition of carapace anterolateral margin, coaptation of carapace and pereopods, condition of male gonopods). This classification has been adopted by subsequent authors (Serène 1984; Ng et al. 2008; De Grave et al. 2009). 
A detailed examination of the morphology of all of the included species of Euxanthinae (sensu $\mathrm{Ng}$ et al. 2008) has shown that it is not a monophyletic grouping, and that Glyptoxanthus is morphologically distinct from all Euxanthinae (see below) as well as other xanthids, thus necessitating the establishment of a separate subfamily for it. These results were corroborated by molecular data from a more inclusive study on the phylogeny of the Xanthidae MacLeay, 1838, using multiple genes as well as larval and adult morphology (Lai et al. in press).

\section{Material and methods}

Measurements for the material examined are shown as carapace length $\times$ carapace width. The terminology of Dana (1851) is used for the designation of the carapace regions, e.g., 2M, 1P, etc. The terms "groove" and "furrow" as used in the context of carapace sculpture are not inter-changeable, "groove" referring to the long depressions delineating and separating the carapace regions and "furrow" to the smaller and shorter depressions within each of the carapace regions.

The following abbreviations are used: a1-a6, abdominal somites 1-6; G1, first male pleopod, or first gonopod; G2, second male pleopod, or second gonopod; mxp1-mxp3, first to third maxillipeds; P1-P5, first to fifth pereopods (P1 as chelipeds). The thoracic somites and sternites are numbered from 1 to 8 . The thoracic sternal sutures are referred to by the number of the two sternites that they involve, and are thus numbered from $1 / 2$ to $7 / 8$. Where stated, "the Code" refers to the International Code of Zoological Nomenclature (ICZN, 1999).

The material examined is deposited in the following collections: Natural History Museum of Los Angeles County, Los Angeles (LACM); Muséum national d'Histoire naturelle, Paris (MNHN); Naturalis, Nationaal Natuurhistorisch Museum, Leiden (RMNH); Smithsonian National Museum of Natural History, Washington, D.C. (USNM); and Zoological Reference Collection, Raffles Museum of Biodiversity Research, Singapore (ZRC).

\section{Systematic account}

\section{Xanthoidea MacLeay, 1838}

\section{Xanthidae MacLeay, 1838}

\section{Glyptoxanthinae nov. subfam.}

\section{Type genus. Glyptoxanthus A. Milne-Edwards, 1879.}

Diagnosis. Carapace transversely ovate, robust; dorsal surface typically ornamented with prominent ridges formed by fused granules, arranged in regular reticulate or vermiculate patterns; surrounded by dense setae; cervical groove deep. Front deflexed, quadrilobate. Anterolateral margins long, arcuate, divided into 4 low lobes, anterior part descending toward buccal cavity; posterolateral margins shorter, deeply concave. Suborbital regions eroded; subhepatic region with narrow canals continuing from grooves on dorsal surface. Orbits small, round. Anterior part of proepistome touching, almost protruding through deep, median notch of front. Basal article of antenna large, subtrapezoidal, advanced ventrally; flagellum short. Epistome small, posterior margin with 2 prominent notches laterally. Endostome with prominent oblique ridges on posterior half. Lacinia of mxp1 not produced transversely. Outer surface of mxp3 eroded; anterior margin of merus deeply notched. Male thoracic sternum narrow, deeply eroded, often with reticulate sculpturing. Thoracic sternal sutures 4/5,5/6 interrupted, with short interruption points, sutures 6/7, 7/8 complete. Sternite 7 narrow, with anterior portion slightly larger than episternite; episternite 7 locking tightly with lateral expansion of abdominal somite 3. Sternal press-button prominent, placed on posterior half of sternite 5. Median line on sternite 4 in anterior, nearly independent, prolongation of sterno-abdominal cavity, then interrupted except for short, recessed groove inside sterno-abdominal cavity, absent on sternite 5, present on postertior half of sternite 6 , entirely extended along sternites 7, 8. Pereopods tightly coapted to carapace and to one another; external surfaces similarly sculpted as carapace. Chelipeds equal, homochelous, homodontus, robust; fingers stout, channeled, blunt. Ambulatory legs short, flattened. Male abdomen long, constricted at junction of somites 5, 6, tip of telson just reaching level of coxo-sternal condyles of cheliped coxae; outer surface with pronounced transverse ridges, vermiculations; somites 3-5 immovably fused, but with sutures visible, complete on 
external surface; somite 3 with abrupt lateral expansions, with cupuliform depressions which receive, interlock with episternite of sternite 7. G1 long, slender, tip blunt, opening apically; distal half armed with spiniform tubercles, only with a few simple terminal setae (0-2), never with long, plumose subterminal setae. G2 short, about onefourth length of G1; slender, slightly curved; terminal process short, about one-fourth length of basal segment, recurved.

Remarks. In the molecular phylogeny of the Xanthidae by Lai et al. (in press: fig. 1), a considerable number of subfamilies as constituted in $\mathrm{Ng}$ et al. (2008) were not entirely supported (e.g., Actaeinae, Euxanthinae, Liomerinae, Xanthinae and Zosiminae). Glyptoxanthus A. Milne-Edwards, 1879 (represented by G. erosus), was found to be basal to a clade containing representatives of Zalasius Rathbun, 1897, Banareia A. Milne-Edwards, 1869, and Calvactaea Ward, 1933 (i.e., Zalasiinae Serène, 1968), instead of being in Euxanthinae Alcock, 1898, where it has been traditionally included. This has led to a re-examination of morphological features that would corroborate this new finding.

Glyptoxanthus has been previously placed under Euxanthinae on account of the anterolateral margins of its carapace descending toward the buccal cavity, the close coaptation of the pereopods and the carapace, as well as similarities in the general form of the carapace, thoracic sternum, pereopods, abdomen and gonopods (Guinot, 1979). In fact it was thought to be closely related to euxanthine genera, such as Lipaesthesius Rathbun, 1898, Carpoporus Stimpson, 1871, Euxanthus Dana, 1851, Hypocolpus Rathbun, 1897, and Visayax Mendoza \& Ng, 2008 (see Rathbun 1930; Guinot 1967; Mendoza \& Ng 2008). Several features, however, argue for the separation of Glyptoxanthus from the Euxanthinae: 1) a quadrilobate front, with the anterior margin of each half deeply notched to allow free movement of antennules (bilobed front, with anterior margins straight or slightly concave in Euxanthinae); 2) anterior margin of mxp3 merus is deeply notched (entire in Euxanthinae); 3) subhepatic regions have narrow canals similar in form to those seen in Banareia A. Milne-Edwards, 1869 (absent in Euxanthinae); 4) epistome is relatively small, its posterior margin with deep, prominent lateral notches (epistome relatively extensive; notches replaced by closed sutures in Euxanthinae); 5) endostome has salient, oblique ridges on its posterior half (absent or poorly developed in Euxanthinae); 6) lacinia of mxp1 is not well produced transversely (lacinia well produced transversely, mesial tip reaching center of endostome in Euxanthinae); 7) sternal press-button is located on the posterior half of sternite 5 , close to suture $5 / 6$ (press-button located on anterior portion of sternite 5 , near suture $4 / 5$ in Euxanthinae); 8) sutures 3/4 and 4/5 are visible and complete externally, but obsolete internally (sutures absent, or remaining as notches on the lateral margins of fused somites in Euxanthinae); 9) a strong locking mechanism between abdominal somite 3 and thoracic sternite 7 in both sexes,, making it difficult to unfold the abdomen from the sternum (locking mechanism between abdominal somite 3 and sternite 7 weak and rudimentary, especially in females, in Euxanthinae); 10) tip of the telson just reaches the level of the coxo-sternal condyles of P1 coxae, never going beyond (anterior to) this level (tip of telson reaching beyond (anterior to) level of condyles of P1 coxae in Euxanthinae); and 11) G1 simple in form, and without long, simple or plumose, subterminal setae (more complex in form with variously shaped apical lobes, and with few to several, long, simple or plumose, subterminal setae in Euxanthinae). These differences are substantial enough to warrant recognizing a separate subfamily for the genus.

Glyptoxanthus, although a sister-group to the Zalasiinae in the molecular tree (Lai et al. in press: fig. 1), and with similar morphologies in the general shape of the carapace, the notched epistome, and the tight coaptation of the pereopods (as in Banareia A. Milne-Edwards, 1869), also cannot be classified under Zalasiinae. Guinot (1976, under Trichiinae De Haan, 1839) discussed and illustrated the main features of the Zalasiinae. One of the primary features of Zalasiinae, the deflexed, flattened and blade-like fingers of the chelipeds, is not seen in Glyptoxanthus, which has thick, robust and deeply channeled fingers. Likewise, the long, narrow, triangular anterior section of the thoracic sternum (fused sternites 1,2 ) which intrudes into the buccal cavity between the bases of the mxp3, is much reduced, shorter and relatively wider in Glyptoxanthus. Furthermore, zalasiines characteristically have pronounced grooves on the anterior portion of the sterno-abdominal cavity in the males, which receive the distal ends of the G1s. The distal portions of the G1s extend beyond the anterior border of the sterno-abdominal cavity and are thus exposed (Fig. 1; also Guinot, 1976: figs. 25, 27). The carapace and pereopods of zalasiines are also typically covered by a dense pilosity. These features are not observed in Glyptoxanthus.

Although many species of Glyptoxanthus had been initially placed in the genus Actaea or have been thought to be related to it, the molecular phylogeny does not support such a relationship. The unique features observed in the carapace, antennae, epistome, endostome, thoracic sternum, male abdomen and male pleopods of Glyptoxanthus, can be similarly used to distinguish it from Actaea De Haan, 1833, and other Actaeinae Alcock, 1898 (also see Fig. $1)$. 

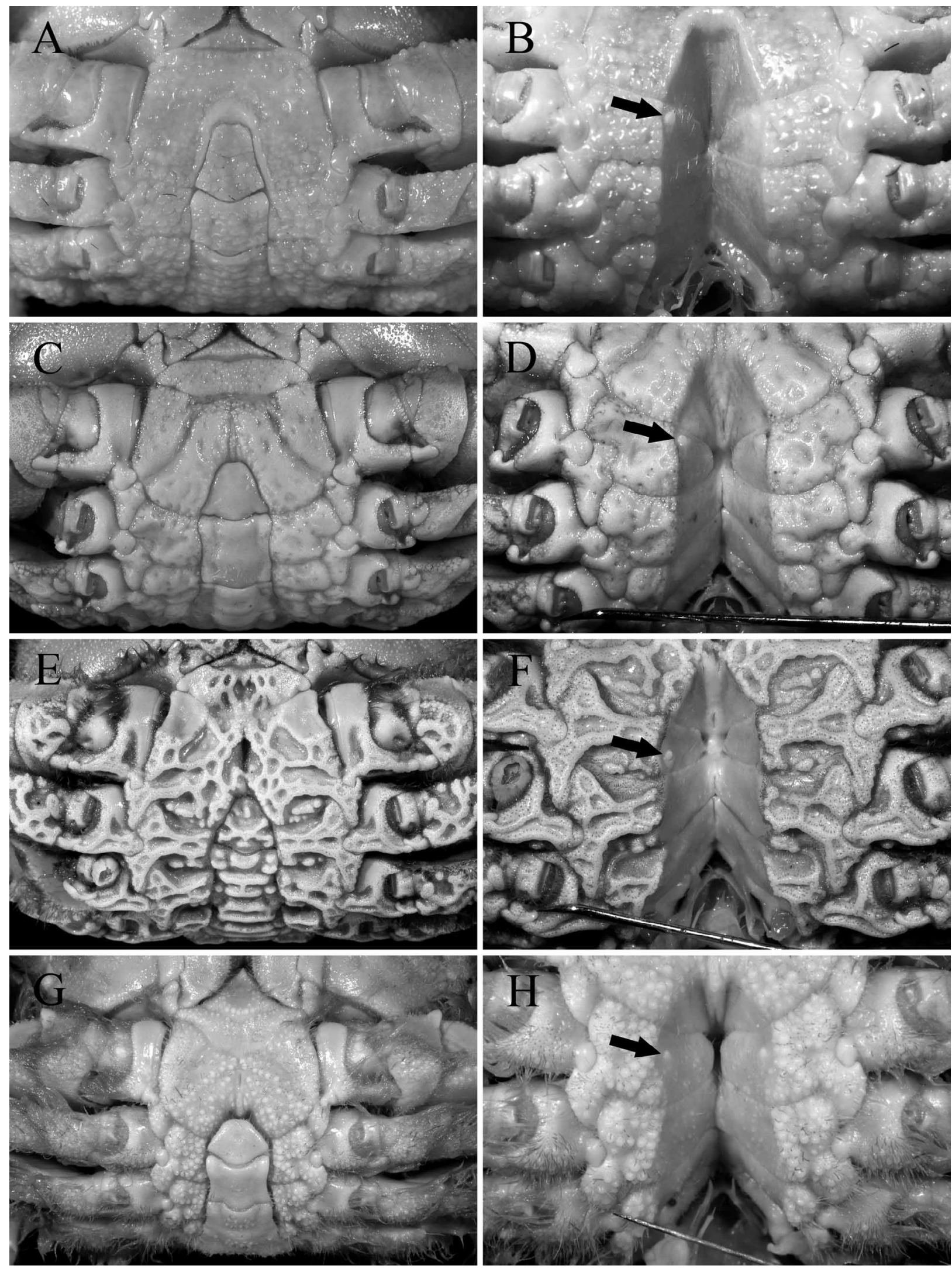

FIGURE 1. Comparison of male thoracic sternums among representative xanthids: A, B, Actaeinae, Actaea semblatae Guinot, 1976 (22.5 × 17.4 mm, ZRC 2011.0700); B, C, Euxanthinae, Euxanthus huonii (Hombron \& Jacquinot, 1846) $(40.3 \times 28.2 \mathrm{~mm}$, ZRC 1987.471); E, F, Glyptoxanthinae subfam. nov., Glyptoxanthus erosus (Stimpson, 1859) $(53.1 \times 38.1 \mathrm{~mm}, \mathrm{ZRC} 1998.9)$; and, G, H, Zalasiinae, Banareia nobilii (Odhner, 1925) $(38.4 \times 26.8 \mathrm{~mm}$, ZRC 2011.0701). Black arrows denote position of sternal press-button. 
As Glyptoxanthus cannot be clearly classified into any existing xanthid subfamily, it is necessary to establish a new subfamily to accommodate it, Glyptoxanthinae nov. subfam.

\section{Glyptoxanthus A. Milne-Edwards, 1879}

Glyptoxanthus A. Milne-Edwards, 1879: 253. —Bouvier 1922: 62. —Rathbun 1930: 263. —Garth 1939: 15; 1946: 437. —Guinot 1967: 554; 1971: 1072; 1979: 65. —Manning \& Holthuis 1981: 135. —Serène 1984: 81. —Williams 1984: 398. —Ng et al. 2008: 199 (list). —De Grave et al. 2009: 43 (list).

Actäa (in part), Klunzinger 1913: 185 [89].

Actaea (in part), Odhner 1925: 35, 57.

Actaea (Glyptoxanthus), Monod 1956: 219. - Serène 1961: 198.

Type species. Actaea erosa Stimpson, 1859, subsequent designation by Rathbun 1930; gender masculine.

Diagnosis. Carapace transversely ovate, broader than long, width-to-length ratio about 1.4, thick when viewed head-on or from the side; regions more-or-less defined but often entirely or partially coalesced, dorsal surface typically ornamented with prominent ridges formed by fused granules, arranged in regular reticulate or vermiculate patterns, surrounded by dense setae; cervical groove between gastro-cardiac and branchial regions deep. Front deflexed, quadrilobate, with deep median notch and deep, lateral concavities on anterior margin. Anterolateral margins long, arcuate, divided into 4 low lobes, anterior part descending toward buccal cavity; posterolateral margins shorter, deeply concave; posterior margin straight. Suborbital regions eroded; subhepatic and pterygostomian regions granulate, setose, subhepatic region with narrow canals continuing from furrows on dorsal surface.

Orbits small, round. Antennules folding obliquely. Anterior part of proepistome touching and almost protruding through deep, median notch of front. Basal article of antenna large, subtrapezoidal, advanced ventrally, and not sunken between front and infraorbital tooth; flagellum short, entering orbital hiatus. Epistome small, posterior margin with 2 prominent notches laterally. Posterior part of endostome with prominent oblique ridges. Lacinia of mxp1 not produced transversely. Mxp3 eroded; anterior margin of merus deeply notched; ischium with deep, submedian sulcus; mesial margin of exopod bulging into matching concavity on ischium, distal end deflected laterally.

Thoracic sternum narrow, deeply eroded, often with reticulate sculpturing; sternite 1 and 2 completely fused, separated from sternite 3 by deep suture; sternite 3 and 4 partially fused at center; median cavity on sternite 4 just anterior to male telson, with short median line within; sterno-abdominal cavity deep; press-button prominent, placed on posterior half of sternite 5; sternite 7 narrow, with anterior portion slightly larger than episternite, which in turn locks very firmly with lateral expansions of-abdominal somite 3 ; sternite 8 entirely covered by abdomen.

Pereopods very tightly coapted to the carapace and to one another. Chelipeds equal, robust, fingers stout and blunt; external surfaces of carpus and palm with granulate, vermiculate lobules surrounded by short setae and deep furrows; merus short, granulate; dactylus and fixed finger with deep, longitudinal channels on external surface, with large, granulate tuberosity on supero-proximal end of dactylus. Ambulatory legs short, flattened; sculpturing on external surfaces similar to that in chelipeds.

Male abdomen long, constricted at junction of somites 5 and 6, tip of telson just reaching level of coxo-sternal condyles of cheliped coxae; outer surface with pronounced transverse ridges and vermiculations; somites 3-5 immovably fused, but with sutures visible and complete on external surface; somite 3 with abrupt lateral expansions, equipped with cupuliform depressions which receive and interlock with episternite of sternite 7.

G1 long, slender, bluntly tipped, opening apically; distal half armed with spiniform tubercles, sometimes with short, simple setae, never with long, plumose, subterminal setae. G2 about one-fourth length of G1.

Remarks. Glyptoxanthus species are rare to uncommon, and are usually found from the intertidal zone to moderate depths $(0-90 \mathrm{~m})$, usually in rocky substrate, and distributed along the western and eastern coasts of the Americas, the Caribbean Sea, the western coast of Africa, and the Red Sea. The different taxa are easily separable by the pattern of the vermiculations on the dorsal surface of the carapace. Their live coloration (variegated or mottled) and their morphology suggest that they are probably sedentary, relying on camouflage to avoid potential predators. Not much is known about their ecology, save for some remarks on the nature of the substrates and the depths from which they have been sampled (e.g., Garth 1946; Manning \& Holthuis 1981). 


\section{Key to species of Glyptoxanthus}

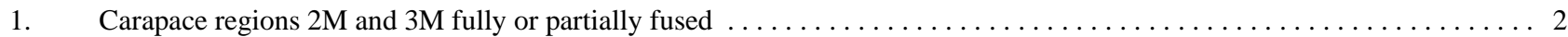

Carapace regions $2 \mathrm{M}$ and $3 \mathrm{M}$ completely separated from each other by wide or narrow groove $\ldots \ldots \ldots \ldots \ldots \ldots \ldots$

2. $3 \mathrm{M}$ fused to internal part of $2 \mathrm{M}$ throughout most of its length; cervical and branchio-cardiac grooves wide, deep; gastric and branchial regions poorly subdivided, vermiculations distinctly anastomosing, reticulate .............. Gorrosus

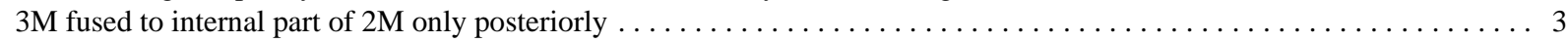

3. 2M completely divided longitudinally; vermiculations smooth, punctuated by small, round cavities......... G. labyrinthicus

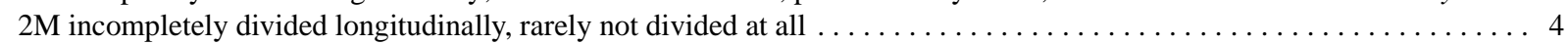
2M clearly but partially divided longitudinally, inner and outer branches fused anteriorly; $1 \mathrm{P}$ with 2 parallel, transverse furrows 2M not clearly divided longitudinally; 1P punctuated with several small, subcircular cavities, never with parallel transverse

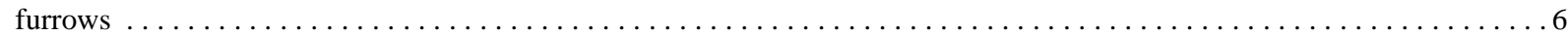

5. Carapace vermiculations relatively thin, simple, the intervening furrows wide; large, oblongate cavity on 5L... G. meandrinus Carapace vermiculations relatively thick, anfractuous, intervening furrows narrow; no large, oblongate cavity on $5 \mathrm{~L} \ldots \ldots$ Carapace vermiculations consisting of fused, small, rounded lobules arranged in linear fashion, or clustered in small circles which resemble "doughnuts"; lobules immediately posterior to $1 \mathrm{P}$ thick, subcircular to oblong .......... G. angolensis Carapace vermiculations continuous within each subregion, more regular, symmetric; lobules immediately posterior to $1 \mathrm{P}$

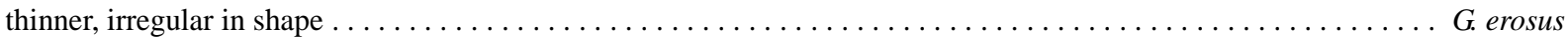

7. Vermiculations and lobules on carapace, thoracic sternum, abdomen and pereopods appearing rough due to several individual, round granules, only partially fused at bases, clearly visible under low magnification ............. G. meandricus

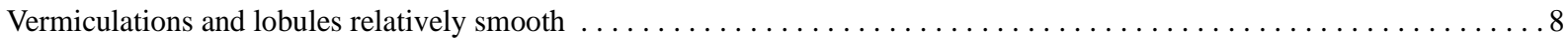

8. Carapace vermiculations thick, petaloid, some assuming a "four-leaf clover" shape; intervening furrows narrow; X-shaped 2P region divided into separate lobules; anterior thoracic sternum weakly eroded, with scattered oblique fissures, particularly on

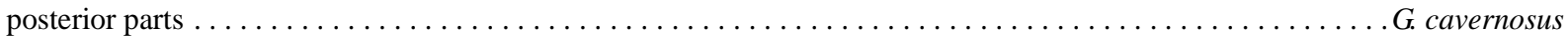
Carapace vermiculations convoluted; intervening furrows relatively wider; $\mathrm{X}$-shaped $2 \mathrm{P}$ region entire; anterior thoracic sternum much eroded, forming regular and symmetric patterns of ridges and cavities .

G. hancocki

\section{Glyptoxanthus angolensis (Brito Capello, 1866)}

(Figs. 2, 10A)

Actaea angolensis Brito Capello, 1866: 4, pl. 1, fig. 3; 1867: 4, pl. 1, fig. 3 (type locality: Angola, west Africa). —Capart 1951: 157, fig. 59. —Longhurst 1958: 88. —Gauld 1960: 70.

Xantho vermiculatus, Osorio 1887: 224; 1898: 192. Not Cancer vermiculatus Lamarck, 1818.

Glyptoxanthus vermiculatus, Rathbun 1900: 288; 1930: 267 (in part). —Balss 1921: 61. Not Cancer vermiculatus Lamarck, 1818.

Actaea (Glyptoxanthus) angolensis, Monod 1956: 296, fig. 361. —Serène 1961: 198 (list).

Glyptoxanthus angolensis, Bouvier 1922: 64. —Forest \& Guinot 1966: 77, fig. 6a, b. —Guinot 1967: 556; 1971: 1073; 1979:

66, fig. 18B, pl. 6 fig. 3. —Manning \& Holthuis 1981: 135 — Ng et al. 2008: 199 (list).

Glyptoxanthus sp., Sourie 1954: 112.

Material examined. Equatorial Guinea: 1 male, $24.7 \times 17.1 \mathrm{~mm}$ (RMNH-D31547), stn 282, $23 \mathrm{~m}, 01^{\circ} 28^{\prime}$ S, 5'36'E, Annobon Is., coll. Pillsbury, 21 May 1965; 1 male, $12.0 \times 8.2$ mm (USNM 127170), drag net, 35-55 m, 01 ${ }^{\circ} 28.5^{\prime}$ S, $5^{\circ} 37.5^{\prime} \mathrm{E}$, south coast of Annobon Is., coll. F. Poinsard, 16 Jun. 1967; 1 female, $16.5 \times 11.3 \mathrm{~mm}$ (USNM 170332), dredge, 16-21 fms (29-38 m), Annobon Is., coll. Pillsbury, 21 May 1965.

Gabon: 1 male, $49.9 \times 34.4$ mm (MNHN-B8352), Mayumbo Verques, Congo Français, 1899 .

Senegal: 1 female, 35.525 .4 mm (MNHN-B7410), Dakar, anse Bernard, coll. Sourie, det. Th. Monod, 1953; 1 male, $13.8 \times 9.6 \mathrm{~mm}$ (RMNH-D40257), stn SEN.08, 0.5-6m, boulder beach, near Lido Hotel, southern tip of Cape Verde Peninsula between Cap Manuel \& Pointe Bernard, coll. 2 Jun. 1982; 1 male, $26.8 \times 18.7$ mm (RMNHD40255), stn SEN.12, snorkelling, 1-5 m, sandy bay between Ile de N'Gor \& Plage du Virage, N coast of Cape Verde Peninsula, coll. 23-24 Nov. 1983; 1 male, $16.8 \times 11.5$ mm, 1 female, $24.0 \times 16.5$ mm (RMNH-D40256), stn SEN.17, snorkelling, 0-4 m, protected bay with sand, stone \& boulders, facing Ile de N'Gor, N coast of Cape Verde Peninsula, La Calao, coll. 28, 30 Nov. —1 Dec. 1983.

Diagnosis. Carapace transversely ovate, width-to-length ratio about 1.4; vermiculations relatively thick and smooth, with traces of fused granules visible under low magnification, some smaller vermiculations resembling "doughnuts" particularly on cardiac and branchial regions; furrows between vermiculations deep, filled with setae; 
$2 \mathrm{M}$ undivided, partially fused with $3 \mathrm{M}$ posteriorly; $4 \mathrm{M}$ fused with $3 \mathrm{M}$ and $1 \mathrm{P}$ by narrow, median bridge; $4 \mathrm{~L}$ distinct; $5 \mathrm{~L}$ and $6 \mathrm{~L}$ united; $1 \mathrm{P}$ with small, round, separate but regularly arranged cavities; cervical furrow deep, moderately broad. Front quadrilobate, with deep lateral notches. Anterolateral margin with 4 feeble lobes; fourth well separated, subtriangular. External surfaces of thoracic sternum, pereopods and abdomen with similar sculpturing as carapace. Margins of ambulatory legs fringed with long setae. G1 long, slender, bluntly tipped; ventral wall of aperture with 2 short, simple setae; G2 about one-fourth length of G1.

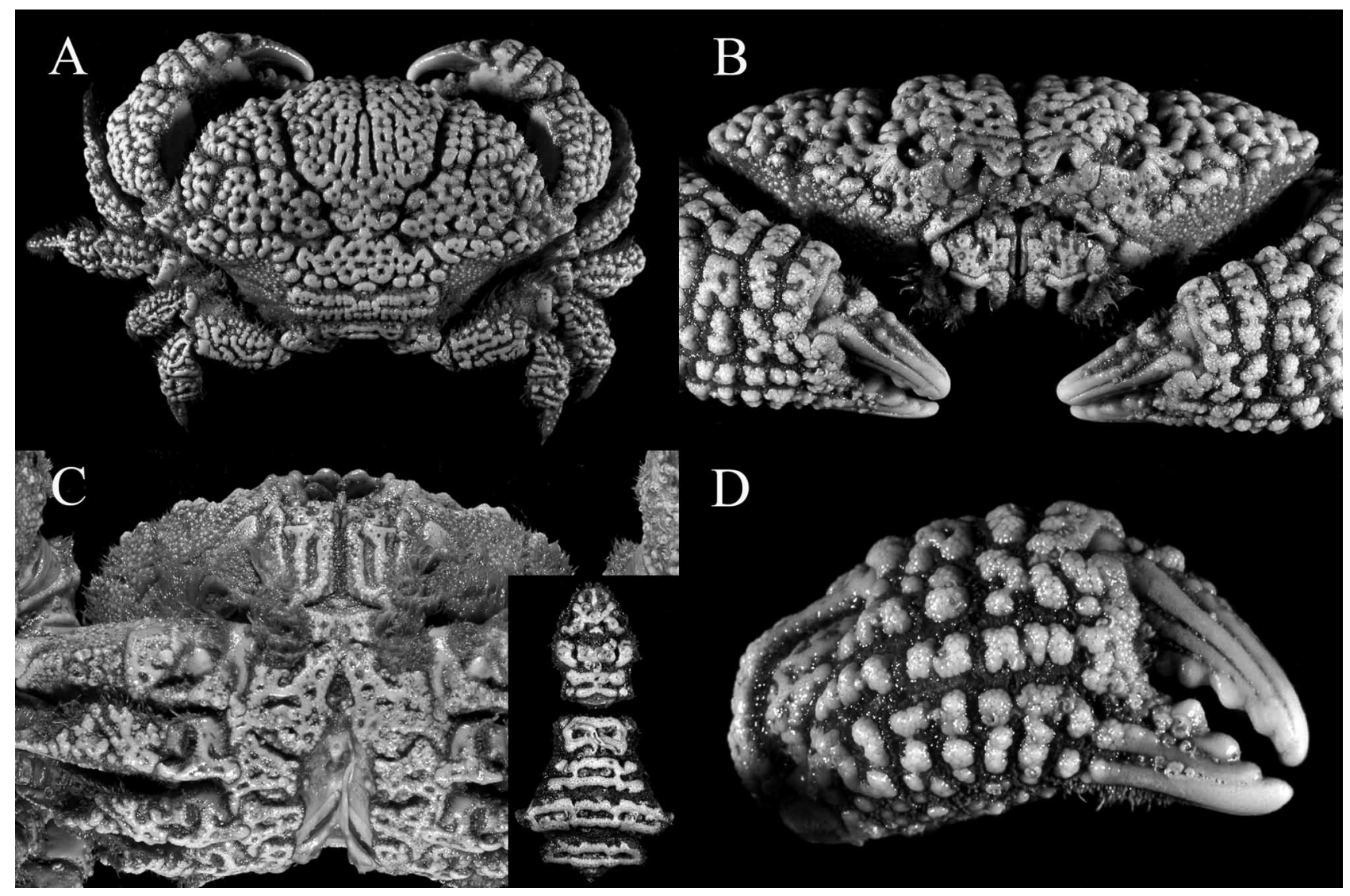

FIGURE 2. Glyptoxanthus angolensis (Brito Capello, 1866), male, $49.9 \times 34.4 \mathrm{~mm}$ (MNHN-B8352), Mayumbo Verques, Gabon: A, dorsal view; B, anterior view; C, ventral view; inset, abdomen; D, right chela, external view.

Remarks. Brito Capello $(1866,1867)$ described Actaea angolensis from Angola, on the southwestern coast of Africa. Some authors (Osorio 1887; Rathbun 1900; Balss 1921) treated it as conspecific with G. vermiculatus (Lamarck, 1818). Capart (1951) and Monod (1956), however, considered these to be two separate species, particularly on the basis of the carapace sculpturing, the live colouration, and the G1 morphology. Glyptoxanthus angolensis is morphologically most similar to G. erosus and to G. vermiculatus in the general shape of the carapace, and the disposition of the carapace regions and vermiculations. However, G. angolensis can be distinguished from these two species by the unique pattern of the carapace vermiculations, particularly in the formation of "doughnut"shaped lobules especially on the branchial and cardiac regions, and by the G1. Glyptoxanthus angolensis can also be distinguished from G. erosus by its less, and irregularly, eroded anterior thoracic sternum (more eroded, but erosions and ridges forming a regular pattern in G. erosus). Furthermore, G. angolensis differs from G. vermiculatus by its poorly divided $2 \mathrm{M}$ region (partially but clearly divided longitudinally in G. vermiculatus) and the discrete subcircular cavities on the 1P region (two transverse parallel furrows on 1P in G. vermiculatus).

The type specimen reportedly deposited at the Museu Nacional de História Natural, Lisbon, Portugal, was not examined in this study. However, several specimens presently deposited at MNHN, RMNH and USNM were examined, which agree with descriptions and illustrations of previous workers (Brito Capello 1866; Capart 1951; Monod 1956; Guinot 1979).

Ecology and geographical distribution. Glyptoxanthus angolensis has been found in shallow to moderate subtidal depths (to $40 \mathrm{~m}$ ), in sandy-rocky, rocky or coralline substrate. It is known to occur on the western coast of 
Africa: Ghana, Senegal, Angola, São Tomé, Annobon, Sierra Leone, and Gabon (see Manning \& Holthuis 1981). The live colouration of this species has been described as generally red, with lighter patches of yellow (Brito Capello 1866) or orange-red with lighter patches (Capart 1951).

\section{Glyptoxanthus cavernosus (A. Milne-Edwards, 1878)}

(Figs. 3, 10B)

Actaea cavernosa A. Milne-Edwards, 1878: 226 (type locality: Cape Verde Is.). —Monod 1933: 523.

Xantho vermiculatus, Osorio 1906: 149. Not Cancer vermiculatus Lamarck, 1818.

Actaea (Glyptoxanthus) cavernosa, Monod 1956: 298, fig. 362. —Serène 1961: 198 (list).

Glyptoxanthus cavernosa, Balss 1921: 61. —Forest \& Guinot 1966: 79.

Glyptoxanthus cavernosus, Bouvier 1922: 66, pl. 6 fig. 3, 5. —Guinot 1967: 551, 553, 556, fig. 31; 1971: 1073; 1979: 68, fig. 18C, pl. 6 fig. 5. —Manning \& Holthuis 1981: 135. —d'Udekem d'Acoz 1999: 229. —Ng et al. 2008: 199 (list).

Material examined. Cape Verde Is.: 1 male, $49.6 \times 35.8$ mm (MNHN-B8329), Stn 148, 10-20 m, Sylvana, coll. Le Comte J. Polignac, 8 May 1913; 1 male, $26.7 \times 19.1 \mathrm{~mm}, 1$ female, $24.9 \times 17.9 \mathrm{~mm}$ (MNHN-B8330), La Praya, 10-30 m, Talisman, 1883; 1 male, $21.7 \times 15.5 \mathrm{~mm}, 1$ female, $27.2 \times 19.7 \mathrm{~mm}$ (RMNH-D40250), stn CANCAP 7.D15, scuba, Baia de Ribeirinha, W coast of São Vicente, coll. 7 Sep. 1986; 1 male, $24.7 \times 17.8 \mathrm{~mm}, 1$ female, $26.7 \times 19.0 \mathrm{~mm}(\mathrm{RMNH}-\mathrm{D} 40251)$, stn CANCAP 7.K18, snorkelling, intertidal to shallow sublittoral, shallow lagoon with corals, SE coast of Sal, coll. 29 Aug. 1986; 1 female, $13.7 \times 9.7 \mathrm{~mm}$ (RMNH-D40253), $42 \mathrm{~m}$, grab, SW of São Tiago, coll. 20 Aug. 1986; 1 female, $15.0 \times 10.8$ mm (RMNH-D40254), stn CANCAP 6.D11, scuba, Baia de São Pedro, SW coast of São Vicente, coll. 20 Jun. 1982.

Canary Is.: 1 female, 19.813 .8 mm (RMNH-D40252), stn CANCAP 6.K01, rocky littoral, tidal pools, near los Christianos, SW Coast of Tenerife, coll. 27, 30 May 1982.

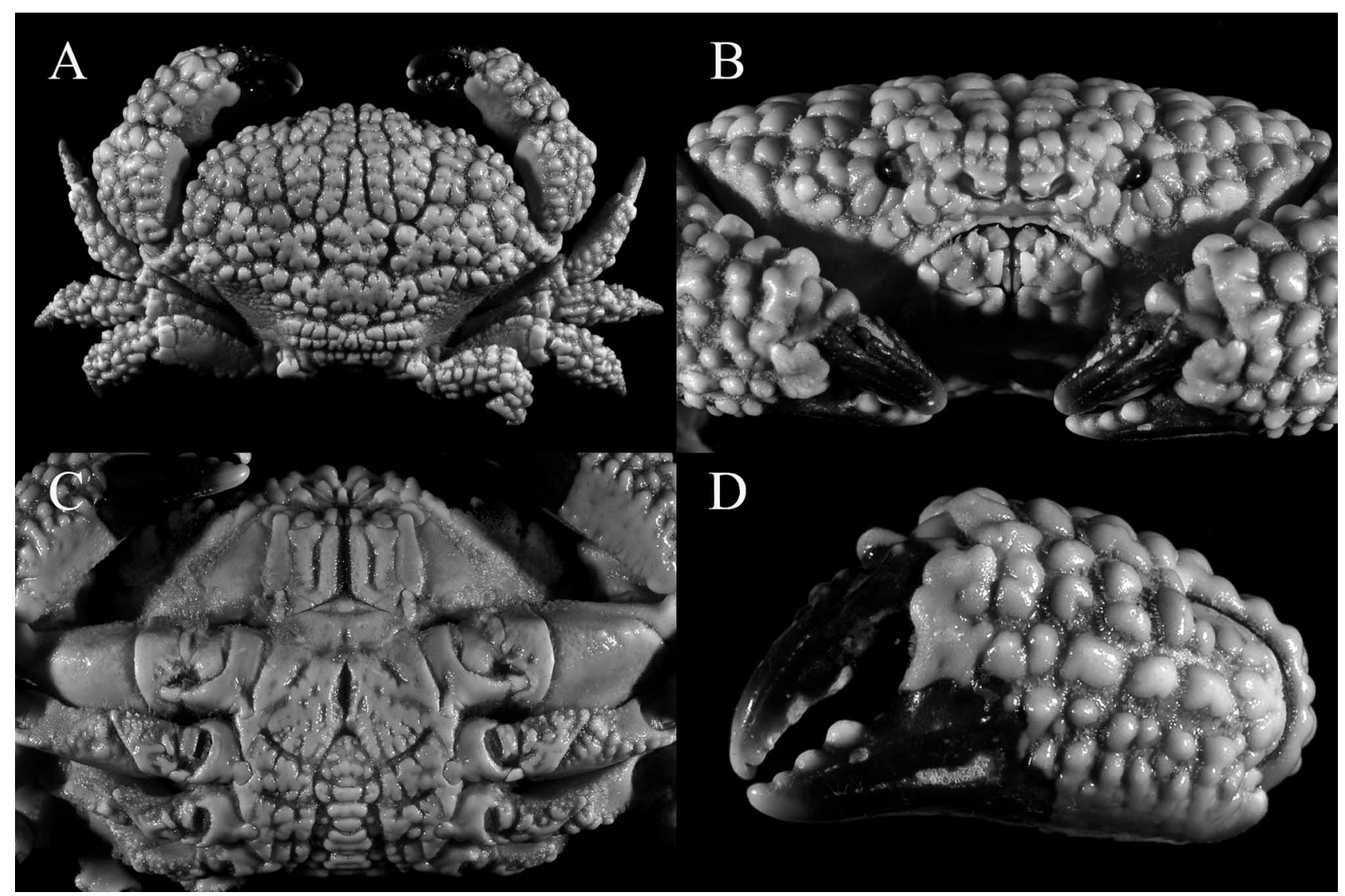

FIGURE 3. Glyptoxanthus cavernosus (A. Milne-Edwards, 1878), male, $49.6 \times 35.8 \mathrm{~mm}$ (MNHN-B8329), Cape Verde: A, dorsal view; $\mathrm{B}$, anterior view; $\mathrm{C}$, ventral view; $\mathrm{D}$, left chela, external view. 
Diagnosis. Carapace transversely ovate, width-to-length ratio about 1.4; carapace vermiculations thick, petaloid, like a pavement of lobules; lobules smooth without traces of individual granules; furrows between lobules deep, relatively narrow, setose; $2 \mathrm{M}$ completely divided longitudinally, inner branch separated from $1 \mathrm{M}$ by shallow transverse furrow; $3 \mathrm{M}$ independent from $2 \mathrm{M}$, posterior region bridged medially with $4 \mathrm{M} ; 2 \mathrm{~L}, 3 \mathrm{~L}$, and $4 \mathrm{~L}$ distinct, $5 \mathrm{~L}$ fused with $6 \mathrm{~L} ; 1 \mathrm{P}$ distinct, independent, without any smaller cavities. Front quadrilobate, with deep lateral notches. Anterolateral margin with 4 feeble lobes. External surfaces of thoracic sternum, pereopods and abdomen with similar sculpturing as carapace. Margins of ambulatory legs fringed with long setae. G1 long, slender, bluntly tipped; apex devoid of any setae, but studded with spiniform granules; G2 about one-fourth length of G1.

Remarks. Alphonse Milne-Edwards (1878) described Actaea cavernosa from the Cape Verde Islands, and later transferred it to his new genus, Glyptoxanthus. Glyptoxanthus cavernosus is easily distinguished from its congeners by the sculpturing on the dorsal surface of its carapace: in particular, the completely independent $3 \mathrm{M}$ region and the closely packed, non-elongate lobules and vermiculations, which have distinctly petaloid outlines. In fact, these vermiculations resemble the closely packed granules of some species of Actaea (see Guinot 1979: fig. 10), and also of some Euxanthus such as E. boletarius (Rathbun, 1911) (see Serène 1984: pl. 11 fig. E).

According to Monod (1956), the type specimen was deposited in the MNHN, Paris, but it could not be found. However, this is a distinctive species that was well described and we have no doubt over the identity of our present material, most of which is from the type locality, Cape Verde Islands.

Ecology and geographical distribution. Glyptoxanthus cavernosus is only known from the Cape Verde Islands and from the Canary Islands, off the northwestern coast of Africa, and has been collected from intertidal to shallow subtidal zones, amidst rocks and coral.

\section{Glyptoxanthus corrosus (A. Milne-Edwards, 1869)}

(Figs. 4, 10D)

Xantho corrosus A. Milne-Edwards, 1869: 376 (type locality: St. Vincent Is., Cape Verde).

Actaea (Glyptoxanthus) corrosa, Monod 1956: 298.

Glyptoxanthus corrosus, Bouvier 1922: 67, pl. 6 figs. 4, 6. —Guinot 1967: 556, fig. 21; 1971: 1073; 1979: 68, figs. 9, 18E. — Manning \& Holthuis 1981: 135. —Ng et al. 2008: 199 (list).

Material examined. Cape Verde: Holotype, male (dry), $26.6 \times 18.7$ mm (MNHN-B3015), St. Vincent Is., coll. M. Bouvier, 1868-1869.

Diagnosis. Carapace transversely ovate, width-to-length ratio 1.4; gastric, branchial, cardiac and intestinal regions well separated by wide and deep furrows, but subregions (i.e., $1 \mathrm{M}+2 \mathrm{M}+3 \mathrm{M} ; 1 \mathrm{~L}+2 \mathrm{~L}+3 \mathrm{~L}+4 \mathrm{~L}+5 \mathrm{~L}+6 \mathrm{~L}$ ) more-or-less fused; 4M distinct, bridging gastric and cardiac regions; carapace vermiculations showing traces of fused granules, anastomosing, forming a regular reticulate pattern, particularly on gastric and branchial regions. Anterolateral margin poorly divided into low lobes, last lobe most definite. Anterior thoracic sternum moderately eroded, with somewhat reticulate sculpturing. G1 long and slender, apex somewhat tapering and devoid of setae, studded with spiniform granules.

Remarks. Alphonse Milne-Edwards (1869) described Xantho corrosus from St. Vincent Island, in the Cape Verde Archipelago, and later (A. Milne-Edwards 1879) he transferred it to his new genus Glyptoxanthus. It is easily distinguished from a sympatric species, G. cavernosus (A. Milne-Edwards, 1878), and from other congeners by the unique sculpturing of the dorsal carapace: i.e. fused carapace subregions, anastomosing and reticulate pattern of vermiculations, and wide and deep cervical and branchio-cardiac grooves.

Ecology and geographical distribution. Glyptoxanthus corrosus is a singular and rare species, only known from the type specimen, which is from Cape Verde, off the northwestern coast of Africa. Very little is known about the biology of this species (see Guinot 1979). 


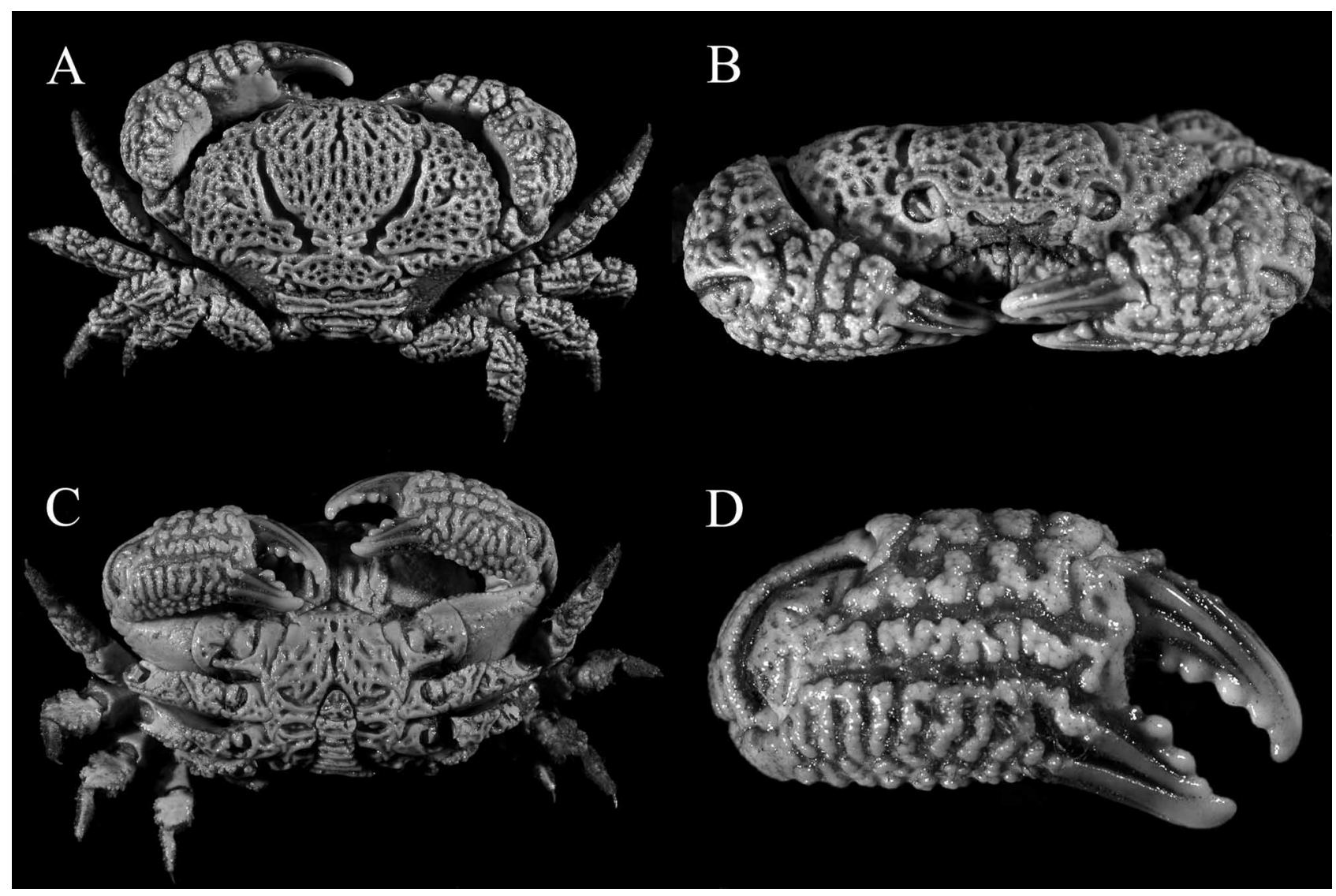

FIGURE 4. Glyptoxanthus corrosus (H. Milne Edwards, 1834), holotype, male, $26.6 \times 18.7$ mm (MNHN-B3015), Cape Verde: A, dorsal view; B, anterior view; C, ventral view; D, right chela, external view.

\section{Glyptoxanthus erosus (Stimpson, 1859)}

(Figs. 1E, F, 5, 10E)

Actaea erosa Stimpson, 1859: 51 (type locality: Florida, U.S.A.).

Glyptoxanthus erosus, A. Milne-Edwards 1879: 254, pl. 43 fig. 3, pl. 44 fig. 4. —Rathbun 1930: 263, pl. 107 figs. 1-4. —Williams 1965: 185, figs. 167, 183A; 1984: 398, figs. 312, 331b. —Guinot 1967: 556, fig. 30a, b; 1971: 1072; 1979: 66, figs. 18D, 23B, pl. 6 fig. 2. - Felder 1973: 60, pl. 9 fig. 9. —Abele \& Kim 1986: 57, 655 fig. c. —Ng et al. $2008: 199$ (list).

Material examined. U.S.A.: Neotype (presently designated), male, $47.3 \times 32.9 \mathrm{~mm}$ (USNM 25573), Biscayne Bay, Florida, coll. G.E. Benedict, 1901.

Other material. 1 male, $25.5 \times 17.9 \mathrm{~mm}$ (MNHN-B8354), Florida, don. Smithsonian Institution, Jul. 1899; 1 male, $47.7 \times 34.5$ mm (USNM 76271), Bird Key reef, Tortugas Is., Florida, coll. Manter, 28 Jun. 1931, don. W.L. Schmitt, det. M.J. Rathbun; 1 male, $44.3 \times 32.8$ mm (USNM 119500), from rocky ledge, $97 \mathrm{ft}, 5$ miles off Destine, Florida, coll. 17 Feb. 1962, det. R.B. Manning; 1 ovig. female, $67.0 \times 47.0$ mm (USNM 168866), Calico scallop grounds, south of Beaufort Islet, North Carolina, coll. H.J. Porter/Ensign, 5 Sep. 1972, det. A.B. Williams; 1 male, $77.2 \times 55.0 \mathrm{~mm}$ (USNM 237609), stn 13, otter trawl, $156 \mathrm{fms}$, USA east coast, coll. R. Lemaitre/RV Bellows; 1 male, $53.1 \times 38.1 \mathrm{~mm}$ (ZRC 1998.9, ex. USNM 168865), 60-65 feet, Sapelo Island, 4.75 miles off Whistle Buoy, Georgia, coll. M. Gray, 7 Apr. 1966, det. A.B. Williams, 1977.

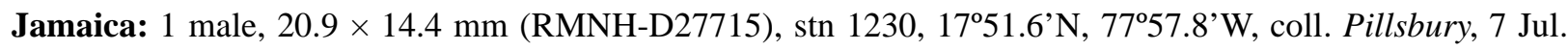
1970, det. L.B. Holthuis.

Mexico: 1 male, $16.3 \times 11.4 \mathrm{~mm}, 2$ females, $14.0 \times 10.4 \mathrm{~mm}, 24.5 \times 17.5 \mathrm{~mm}, 1$ juv., $5.8 \times 4.7 \mathrm{~mm}$ (USNM 9585), stn. 2365, $44 \mathrm{~m}$ (24 fms), $22^{\circ} 18^{\prime} 00^{\prime \prime N} 87^{\circ} 04^{\prime} 00^{\prime \prime} \mathrm{W}$, north of Yucatan Peninsula, Gulf of Mexico, coll. Albatross, 30 Jan. 1885; 2 males, $12.7 \times 8.9 \mathrm{~mm}, 26.9 \times 19.1 \mathrm{~mm}, 1 \mathrm{female}, 22.8 \times 16.5 \mathrm{~mm}$ (USNM 15001), off Yucatan Peninsula, stn 2363, coll. Albatross, 1885. 


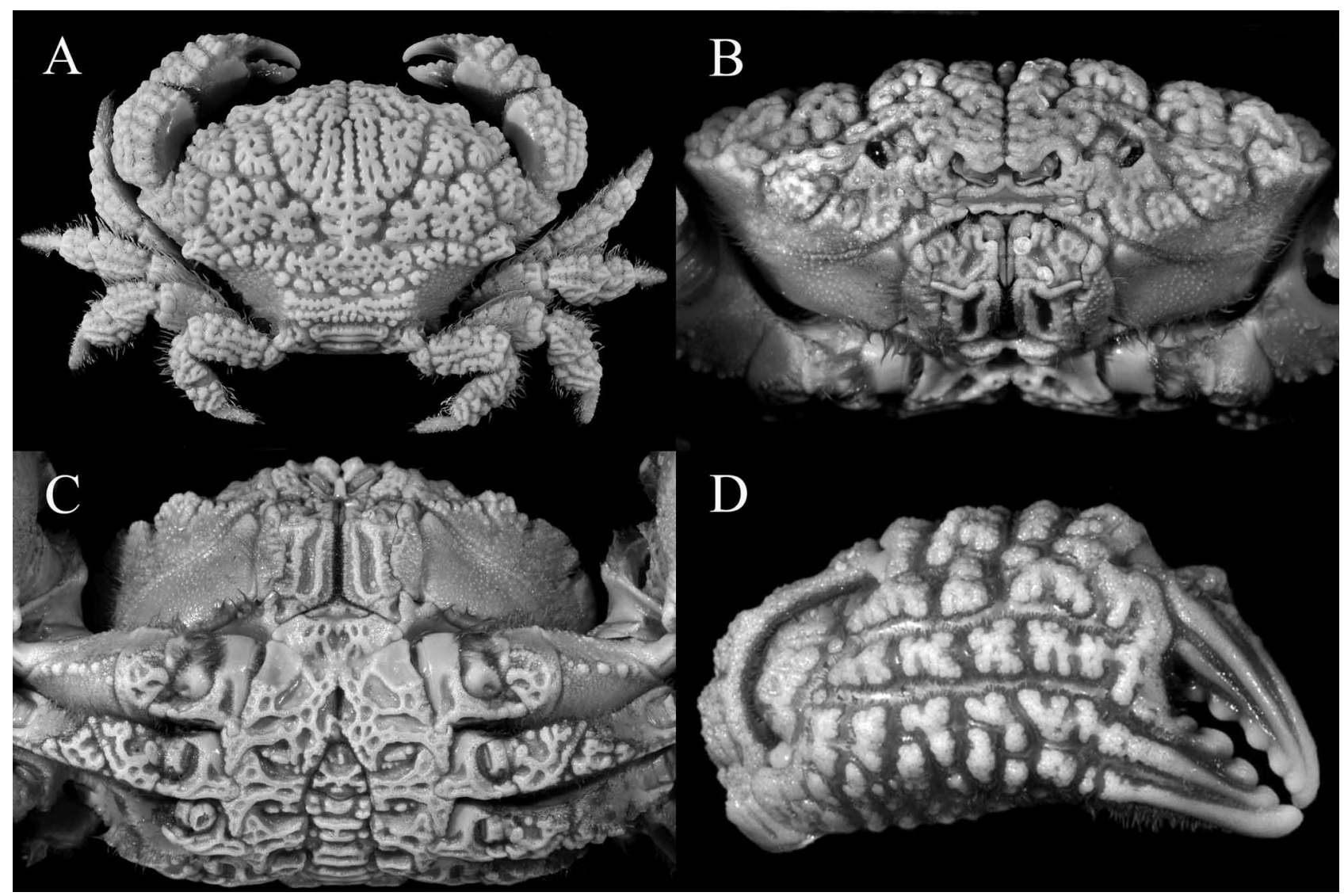

FIGURE 5. Glyptoxanthus erosus (Stimpson, 1859), A, neotype, male, $47.3 \times 32.9 \mathrm{~mm}$ (USNM 25573), Florida, dorsal view; B-D, male, $53.1 \times 38.1 \mathrm{~mm}$ (ZRC 1998.9), Georgia (USA), B, anterior view; C, ventral view; D, right chela, external view.

Diagnosis. Carapace transversely ovate, width-to-length ratio about 1.4; regions more-or-less defined, with several small, discrete, subcircular cavities included within; cervical groove deep; $1 \mathrm{M}$ fused to $2 \mathrm{M} ; 2 \mathrm{M}$ poorly divided or entire, fused to $3 \mathrm{M}$ posteriorly; $4 \mathrm{M}$ bridging $3 \mathrm{M}$ and $1 \mathrm{P} ; 2 \mathrm{~L}, 3 \mathrm{~L}, 4 \mathrm{~L}$ distinct; $5 \mathrm{~L}$ and $6 \mathrm{~L}$ fused; $2 \mathrm{P} \mathrm{X}$ shaped; vermiculations regular, symmetric, rather convoluted, retaining traces of fused granules; small lobules immediately posterior to $1 \mathrm{P}$ slender and irregular in shape. Front quadrilobate. Anterolateral margin arcuate; divided into 4 low lobes; first lobe smallest, but prominent; fourth lobe subtriangular. Mxp3 deeply eroded. Male thoracic sternum also severely eroded, with cavities of various sizes arranged between granulate ridges in a moreor-less symmetric fashion. External surfaces of pereopods with similar vermiculate sculpturing as carapace. Abdomen with several transverse ridges on external surface, some of which are bridged together by one or shorter, longitudinal ridges. G1 long and slender, dorso-lateral wall of apex forming a narrow hood over aperture; with 1 or 2 short, simple setae on ventral margin of aperture; studded with spiniform granules subdistally; G2 about one-fourth length of G1.

Remarks. Stimpson (1859) described Actaea erosa from Florida, U.S.A. Alphonse Milne-Edwards (1879) subsequently transferred this species to Glyptoxanthus, along with other species previously in Actaea and Xantho, but did not formally designate a type species. Rathbun (1930) designated G. erosus as type species of Glyptoxanthus, and also reported that Stimpson's type was no longer extant, but did not select a neotype. A large male specimen $(47.3 \times 33.0 \mathrm{~mm}$, USNM 25573), from Biscayne Bay, Florida, and figured by Rathbun (1930: pl. 107), is designated here as the neotype of G. erosus, in accordance with Article 75 of the Code. This action is deemed necessary for the stability of the genus and species, as G. erosus is the type species of the genus, and as there are similar and/or sympatric species, such as G. vermiculatus and G. angolensis, with which it can be confused.

Glyptoxanthus erosus is easily distinguished from G. vermiculatus with which it shares part of its distributional range, by the presence of several, small, disjunct, subcircular cavities on the cardiac region (1P) (two transverse, parallel furrows on 1P in G. vermiculatus). Except for their separate distributional ranges, G. erosus could be easily confused with G. angolensis due to the strong similarities in their carapace sculpturing; although G. erosus tends to 
have more regular and symmetric vermiculations than G. angolensis, and also does not have the "doughnut"-like vermiculations observed in G. angolensis (see Remarks for G. angolensis). The morphology of the G1 of these three related species varies considerably from each other (Fig. 10). Rathbun (1930: 265) noted the colouration of a formalin-preserved specimen as "cream white with blotches and small spots of bright red, color especially persistent on walking legs, with dactyls red at base and yellowish distally."

Ecology and geographical distribution. Glyptoxanthus erosus has been reported from the Atlantic coast of the United States (North Carolina to Florida), from the Gulf of Mexico, the Bahamas, the Yucatan Peninsula, and from the Caribbean Sea (see Rathbun 1930; Guinot 1979; Williams 1984). G. erosus has generally been collected subtidally from sandy to rocky and coralline bottoms to a maximum depth of $90 \mathrm{~m}$ (see Williams 1984).

\section{Glyptoxanthus hancocki Garth, 1939}

(Fig. 6)

Glyptoxanthus labyrinthicus, Rathbun 1930: 266 (in part). Not Actaea labyrinthicus Stimpson, 1860.

Glyptoxanthus hancocki Garth, 1939: 15, pl. 4 fig. 1, pl. 5 figs. 1a, 2a, 3a (type locality: Galapagos Is.); 1946: 437, pl. 76 figs. 1, 2. —Guinot 1967: 556; 1971: 1073; 1979: 68, pl. 6 fig. 8. —Ng et al. 2008: 199 (list).

Material examined. Ecuador (Galapagos Is.): Holotype, female, $25.8 \times 18.0 \mathrm{~mm}$ (LACM CR 1938.058.1), stn 796-38, shore rock, Sullivan Bay, James Is., coll. Velero/A. Hancock Pacific Expedition, 21 Jan. 1938. Paratypes: 1 male, $26.8 \times 18.5 \mathrm{~mm}$ (LACM CR 1938.058.2), same as holotype; 2 males, $16.0 \times 11.0 \mathrm{~mm}, 32.4 \times 21.8 \mathrm{~mm}$ (LACM CR 1933.107.2), stn 101-33, shore, Darwin Bay, Tower Is., coll. Velero/A. Hancock Pacific Expedition, 26 Feb. 1933.

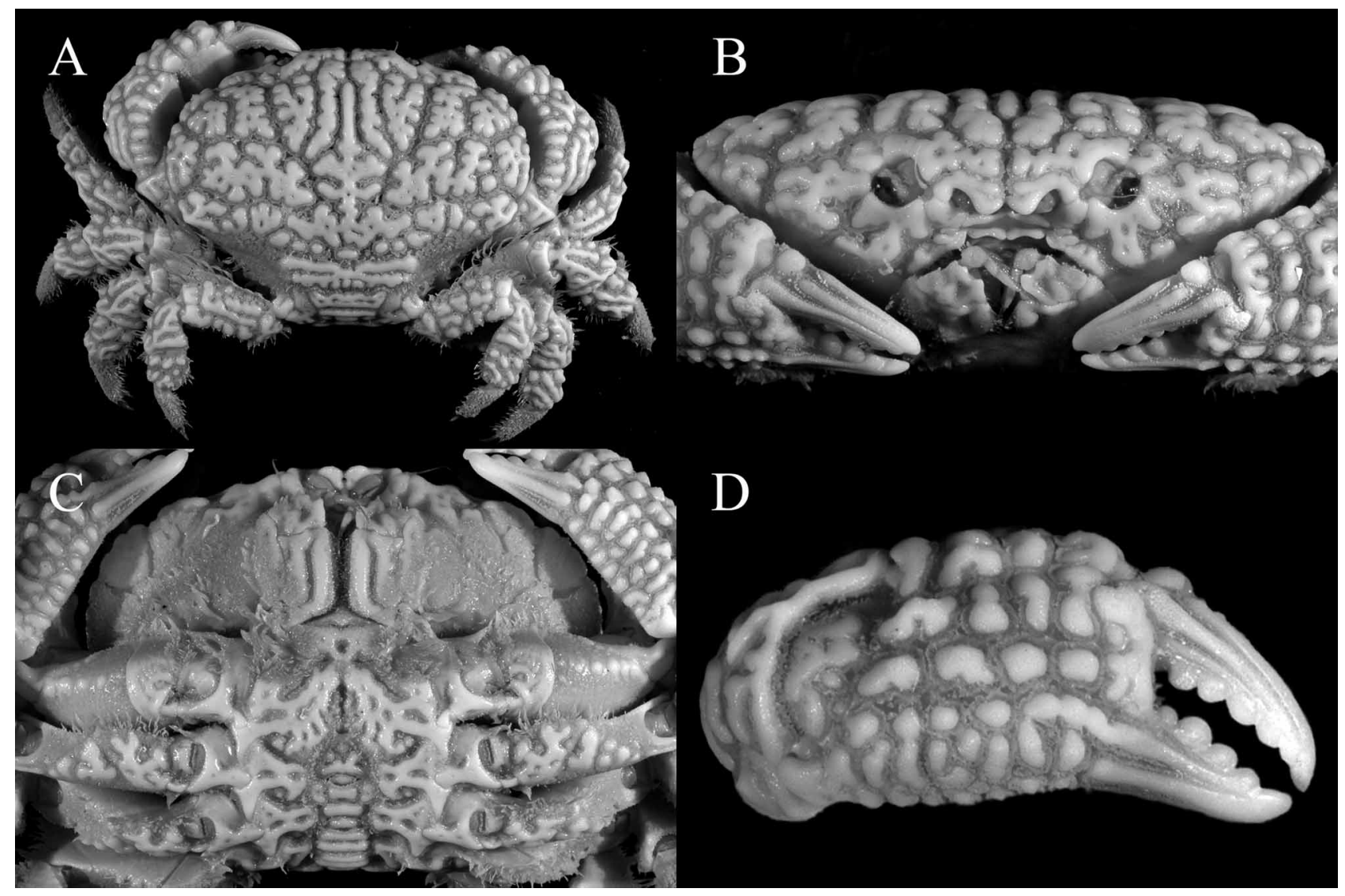

FIGURE 6. Glyptoxanthus hancocki Garth, 1939, paratype, male, $32.4 \times 21.8$ mm (LACM CR 1933.107.2), Galapagos Is.: A, dorsal view; $\mathrm{B}$, anterior view; $\mathrm{C}$, ventral view; $\mathrm{D}$, right chela, external view.

Other material. 1 male, $37.9 \times 25.5$ mm (LACM CR 1934.187.2), stn 313-35, shore, Black Beach, Charles Is., coll. Velero/A. Hancock Pacific Expedition, 6 Dec. 1934; 1 male, $19.0 \times 13.1$ mm, 2 females, $15.9 \times 11.0$ mm, 19.4 
$\times 13.3$ mm (LACM CR 1938.058.22), stn 796-38, shore, Sullivan Bay, James Is., coll. Velero/A. Hancock Pacific Expedition, 21 Jan. 1938; 1 female, $29.3 \times 19.3$ mm (LACM CR 1938.062.2), stn 800-38, shore, Cartago Bay, Albemarle Is., coll. Velero/A. Hancock Pacific Expedition, 22 Jan. 1938; 1 male, $16.2 \times 11.3$ mm, 2 females, $20.5 \times$ 14.3 mm, stn 803-38, shore, Black Beach, Charles Is., coll. Velero/A. Hancock Expedition, 23 Jan. 1938.

Diagnosis. Carapace transversely ovate, width-to-length ratio about 1.4-1.5; dorsal surface rather depressed; regions well defined, with intervening furrows relatively wide, not less pronounced than cervical groove, setose; vermiculations symmetrically convoluted on left and right side of carapace, smooth, with fewer included cavities compared to congeners; $1 \mathrm{~F}, 2 \mathrm{~F}$ distinct; $2 \mathrm{M}$ completely divided longitudinally, $1 \mathrm{M}$ fused to inner branch; $3 \mathrm{M}$ completely independent of $2 \mathrm{M}$, but bridged by $4 \mathrm{M}$ to $1 \mathrm{P} ; 2 \mathrm{~L}, 3 \mathrm{~L}, 4 \mathrm{~L}$ distinct, $5 \mathrm{~L}$ and $6 \mathrm{~L}$ fused. Anterolateral margin arcuate, divided into 4 weakly projecting lobes. Male thoracic sternum eroded, but with symmetric pattern of ridges and cavities. External surfaces of pereopods similarly sculpted as dorsal carapace. Male abdomen with transverse ridges. G1 not figured.

Remarks. Rathbun (1930) assigned one female specimen from the Galapagos Islands to Glyptoxanthus labyrinthicus (Stimpson, 1960). Garth $(1939,1946)$ subsequently assigned this specimen to a new species, Glyptoxanthus hancocki, along with more type material collected from the Galapagos. G. hancocki is most similar to $G$. labyrinthicus, a Pacific species, based on the general shape and sculpturing of the carapace and thoracic sternum. However, the two can be easily distinguished by the following features: 1) $1 \mathrm{~F}$ and $2 \mathrm{~F}$ are not connected to each other in G. hancocki (fused in G. labyrinthicus); 2) the inner branch of $2 \mathrm{M}$ is not fused to the posterior part of $3 \mathrm{M}$ (fused in G. labyrinthicus); 3) the lobes of the carapace anterolateral margin are not well produced (well produced, particularly the fourth lobe, in G. labyrinthicus); and 4) the carapace vermiculations have fewer punctae, i.e. none on inner branch of $2 \mathrm{M}$ and 3 on $3 \mathrm{M}$ (vermiculations with more punctae, i.e., about 5 on inner branch of $2 \mathrm{M}$ and on $3 \mathrm{M}$, in G. labyrinthicus).

Garth (1946: 438) described the live colouration of this species as such: "Dark areas on carapace a rich violet carmine, a little more reddish on branchial and posterior areas. Light areas cadmium orange on frontal, gastric, and cardiac regions; branchial and intestinal regions same color but lighter in tone. Chela violet carmine on dark areas; fingers very dark seal brown, fading toward tips, which are almost white. Ambulatory legs burnt lake on dark areas and light cadmium orange on light areas. Nail of dactyl amber. Eyestalk pale orange yellow; eye blackish brown."

Ecology and geographical distribution. Glyptoxanthus hancocki is known only from the Galapagos Islands, off the coast of Ecuador. It has been collected from rocky substrate (usually under large rocks) in the intertidal zone, during very low tides (see Garth 1946).

\section{Glyptoxanthus labyrinthicus (Stimpson, 1860)}

(Figs. 7, 10F)

Actaea labyrinthica Stimpson, 1860: 204 [76] (type locality: Panama).

Glyptoxanthus labyrinthicus, A. Milne-Edwards 1879: 255, pl. 43 fig. 4. —Rathbun 1930: 266 (in part), pl. 108 figs. 1-3. — Garth 1939: pl. 4 fig. 2, pl. 5, figs. 1b, 2b, 3b. —Guinot 1967: 556; 1971: 1072; 1979: 68, pl. 6 fig. 4. —Ng et al. $2008: 199$ (list).

Material examined. Panama: Neotype (presently designated), female, $31.1 \times 21.7 \mathrm{~mm}$ (USNM 1083419), Bella Vista, Panama Bay, Gulf of Chiriqui.

Other material. 1 female, $10.4 \times 7.2 \mathrm{~mm}$ (LACM CR 1941.3721), stn 104, 8-10 m (4.5-5.5 fms), Guayabo Chiquito, coll. Askoy Expedition, 20-21 May 1941; 1 male, 19.9 $\times 13.6$ mm (USNM 20604), Pacific coast of Panama, coll. Albatross, 12 Mar. 1891; 3 males, $28.5 \times 19.7 \mathrm{~mm}-52.8 \times 35.8 \mathrm{~mm}, 3$ females, $33.8 \times 23.5 \mathrm{~mm}-53.2$ $\times 37.0 \mathrm{~mm}, 1$ ovig. female, $40.5 \times 28.3 \mathrm{~mm}$ (USNM 284119), Pacific coast of Panama, coll. E.D. Robson, det. J.S. Garth.

Colombia: 1 male, $19.0 \times 12.8$ mm (LACM CR 1935.0753), stn 435-35, Octavia Bay, coll. A. Hancock Pacific Expedition, Velero, 28 Jan. 1935.

Mexico: 1 female (dry), $45.1 \times 32.2 \mathrm{~mm}$ (MNHN-B4260), Pacific coast, no other data.

Diagnosis. Carapace transversely ovate, width-to-length ratio 1.4-1.5; regions well defined, intervening furrows similarly wide, setose; $2 \mathrm{M}$ completely divided longitudinally, inner branch fused to $1 \mathrm{M}$ and posterior part of $3 \mathrm{M}$; $4 \mathrm{M}$ bridging $3 \mathrm{M}$ to $1 \mathrm{P} ; 2 \mathrm{~L}, 3 \mathrm{~L}, 4 \mathrm{~L}$ distinct, $5 \mathrm{~L}$ and $6 \mathrm{~L}$ fused; $2 \mathrm{P}$ transversely $\mathrm{X}$-shaped, entire; vermiculations 
generally smooth, anfractuous, punctate. Anterolateral margin arcuate, divided into moderately produced lobes, fourth most distinct, subtriangular. Male thoracic sternum eroded, but with symmetric pattern of ridges and cavities. External surfaces of pereopods similarly sculpted as dorsal carapace. Male abdomen with transverse ridges. G1 long and slender, tip bluntly rounded, devoid of setae, studded with spiniform granules; G2 one-fourth length of G1.

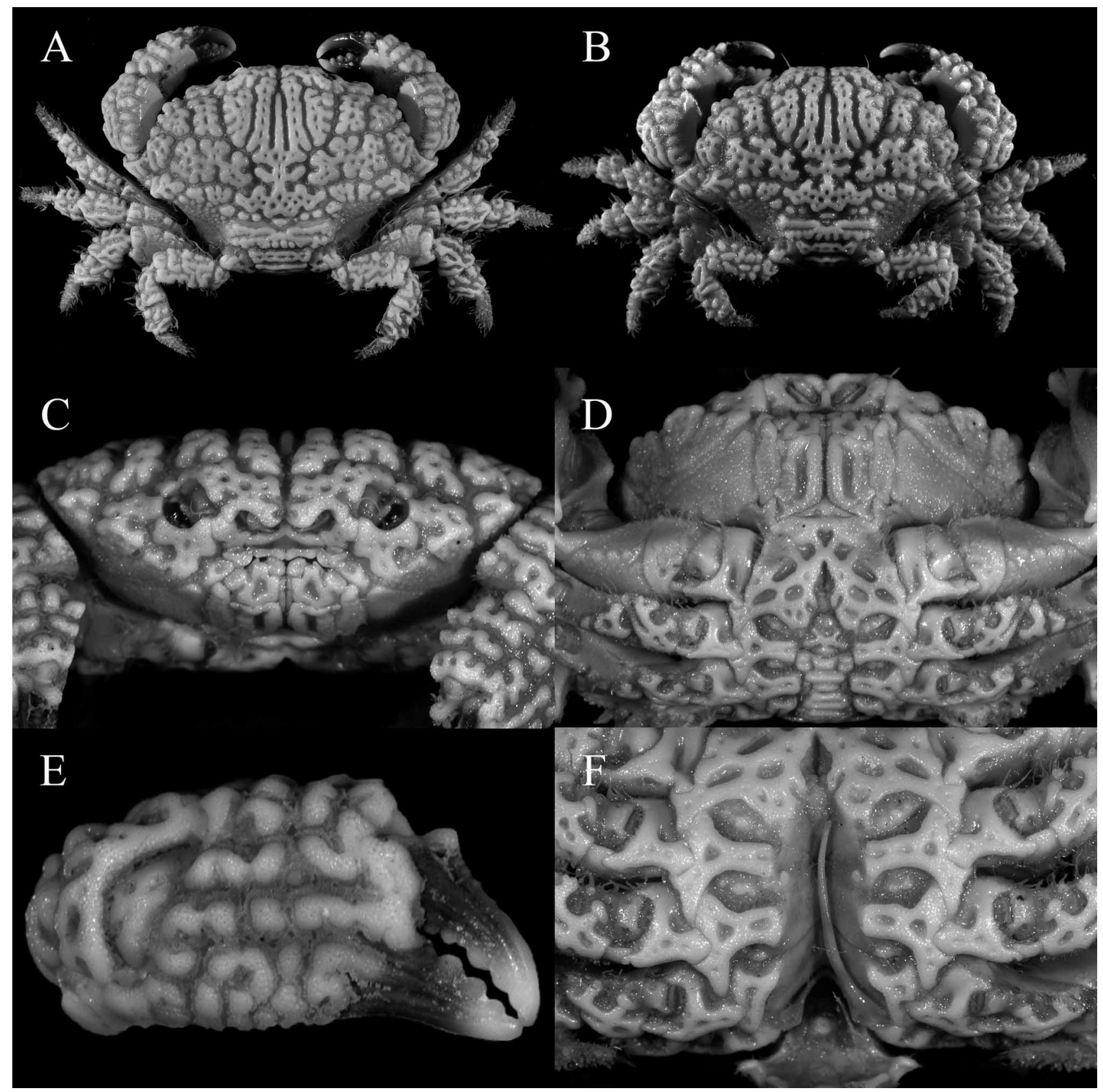

FIGURE 7. Glyptoxanthus labyrinthicus (Stimpson, 1860), A, neotype, female, $31.1 \times 21.7 \mathrm{~mm}$ (USNM 1083419), Pacific coast of Panama, dorsal view; B-F, male, $19.0 \times 12.8$ mm (LACM CR 1935.0753), Octavia Bay, Colombia: B, dorsal view; C, anterior view; D, ventral view; E, right chela, external view; F, posterior sternum \& sterno-abdominal cavity.

Remarks. Stimpson (1860) described Actaea labyrinthica from the Pacific coast of Panama. This species was later transferred by A. Milne-Edwards (1879) to Glyptoxanthus. Rathbun (1930: 266) reported that Stimpson's type specimen was no longer extant, but did not designate a neotype. A female specimen $(31.1 \times 21.7 \mathrm{~mm}$, USNM 1083419), collected from Bella Vista, on the Pacific coast of Panama is here designated as neotype, in accordance with Article 75 of the Code. This action is necessary to stabilize the taxonomy of this species and to avoid confusion with a similar species also known from the eastern Pacific, G. hancocki. 
Glyptoxanthus labyrinthicus is morphologically most similar to G. hancocki Garth, 1939, particularly in the general form and sculpturing of the carapace and thoracic sternum, but a closer examination reveals some consistent differences between the two species (see Remarks on G. hancocki). Stimpson (1860) (see Rathbun, 1930: 266) described the live colouration of this species as "variegated with yellow and carmine." A recent photograph of the same species collected in Panama (kindly provided by Dr. Arthur Anker) shows the vermiculations to be generally variegated with rose-pink, orange and lavender, with bold splotches of darker purple on the posterior branchials, parts of the cardiac and intestinal regions, and on the pereopods, and a vivid vermillion on the anterior parts of the inner halves of the $2 \mathrm{M}$ region; the grooves, as well as the edges of the ambulatory legs are filled with light-brown setae.

Ecology and geographical distribution. Glyptoxanthus labyrinthicus has been reported from the Pacific coast of the Americas, particularly from Panama (type locality), Colombia, and Mexico.

\section{Glyptoxanthus meandricus (Lockington, 1877)}

(Figs. 8, 10G)

Actaea meandrica Lockington, 1877: 97 (type locality: Mulegé Bay, Gulf of California, Mexico).

Glyptoxanthus labyrinthicus, Rathbun 1930: 266 (in part). Not Actaea labyrinthica Stimpson, 1860.

Glyptoxanthus felipensis Rathbun, 1933: 147 (type locality: San Felipe, Gulf of California, Mexico). —Crane 1937: 70, pl. 6 figs. $20,21$.

Glyptoxanthus meandricus, Glassell 1934: 301. —Garth, 1939 pl. 4 fig. 3, pl. 5 figs. 1c, 2c, 3c. —Guinot 1967: 556; 1971: 1072; 1979: 68, pl. 6 fig. 1. —Ng et al. 2008: 197 (list).

Material examined. Mexico: Neotype (here designated), male, $40.7 \times 27.1 \mathrm{~mm}$ (LACM CR 1940.65), intertidal

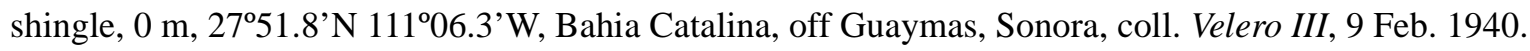

Other material: 3 males, $25.8 \times 17.5 \mathrm{~mm}-46.0 \times 30.2 \mathrm{~mm}$ (LACM CR 1940.65), same data as neotype; 1 female, $33.9 \times 23.0 \mathrm{~mm}$ (MNHN-B8362), Gulf of California, coll. Diquet, 1900, det. D. Guinot, 1976; 1 male, 24.9 $\times 16.7$ mm (LACM CR 1500.024.1), Punta Peñasco, Sonora, coll. J. Littlepage, det. G. labyrinthicus by J.S. Garth.

Types of Glyptoxanthus felipensis Rathbun, 1933: holotype, female, $44.0 \times 28.5 \mathrm{~mm}$ (USNM 67569); paratypes, 4 males, $16.9 \times 11.3-36.6 \times 24.5 \mathrm{~mm}, 3$ females, $22.6 \times 15.4 \mathrm{~mm}-37.1 \times 24.9 \mathrm{~mm}$ (USNM 67569), 1 male, $24.3 \times 16.1 \mathrm{~mm}$, 1 female, $30.3 \times 21.2 \mathrm{~mm}$, (LACM CR 19332085), San Felipe, Gulf of California, coll. H.N. Lowe, 6-15 May 1933.

Diagnosis. Carapace transversely ovate, width-to-length ratio about 1.5; regions more-or-less defined, some deeply punctate; intervening furrows narrow, setose; $2 \mathrm{M}$ completely divided longitudinally, inner branch fused with $1 \mathrm{M} ; 3 \mathrm{M}$ completely independent of $2 \mathrm{M} ; 4 \mathrm{M}$ abutting $3 \mathrm{M}$, but separated from $1 \mathrm{P}$ by irregular furrow; $2 \mathrm{~L}, 3 \mathrm{~L}$, $4 \mathrm{~L}$ distinct, $5 \mathrm{~L}$ and $6 \mathrm{~L}$ fused, cervical furrow deep and wide at level of $6 \mathrm{~L}$ and $4 \mathrm{M} ; 1 \mathrm{P}$ anfractuous; $2 \mathrm{P}$ divided into smaller asperate lobules; vermiculations pronouncedly granular, narrow, convoluted. Front quadrilobate. Anterolateral margin arcuate, weakly divided into 4 lobes, none of which are distinct. Male thoracic sternum with reticulate pattern of narrow, granulate ridges, between shallow, granulate cavities. External surfaces of pereopods with similar sculpturing as carapace. Abdomen with parallel, transverse, granulate bars on external surface. G1 long and slender; terminal end bluntly tipped, studded with spinose granules; ventral margin of aperture with 2 short, simple setae; G2 about one-fourth length of G1.

Remarks. Lockington (1877) described Actaea meandrica from the Gulf of California, but did not provide any illustration. This species was not included when A. Milne-Edwards (1879) established the genus Glyptoxanthus, and in fact, there was no further mention of it until 1930. Rathbun (1930) included this species in the synonymy of Glyptoxanthus labyrinthicus (Stimpson, 1860), without having examined any specimen as, according to her, the types were no longer extant. She later described a new species, Glyptoxanthus felipensis Rathbun, 1933, also from the Gulf of California. Glassell (1934), however, considered G. meandricus (Lockington) as distinct from G. labyrinthicus (Stimpson), and this view was also supported by Garth (1939). Furthermore, Guinot $(1967,1979)$ considered G. felipensis as a junior synonym of G. meandricus (Lockington). Ng et al. (2008) correctly listed G. felipensis as a junior synonym of G. meandricus, but attributed the latter name to the wrong author, Klunzinger, having confused it with another species, G. meandrinus (Klunzinger, 1913), from the Red Sea. To stabilize the taxonomy of this species, a neotype male $(40.7 \times 27.1 \mathrm{~mm})$, collected from the Gulf of California and deposited at the Natural 
History Museum of LA County, in Los Angeles, USA (LACM CR 1940.65), is hereby designated in accordance with Article 75 of the Code. This action is necessary to provide a definite name-bearing type on which to base future comparisons, as the original description of this species by Lockington is rather vague; and also to distinguish it from other species of Glyptoxanthus occurring in the eastern Pacific, although this is the only species known to occur in the Gulf of California.

Glyptoxanthus meandricus is easily distinguished by the narrow and strongly granulate vermiculations on its carapace (and pereopods), which are separated by correspondingly narrow furrows; the independent $3 \mathrm{M}$ and the completely divided $2 \mathrm{M}$ regions; the poorly produced lobes on the carapace anterolateral margins; and the reticulate pattern of narrow ridges and shallow cavities, both of which are granulate, on the thoracic sternum.

Some of the preserved specimens we have examined had a uniform, dark reddish-brown colouration, and had the furrows on the exposed surfaces filled with mud.

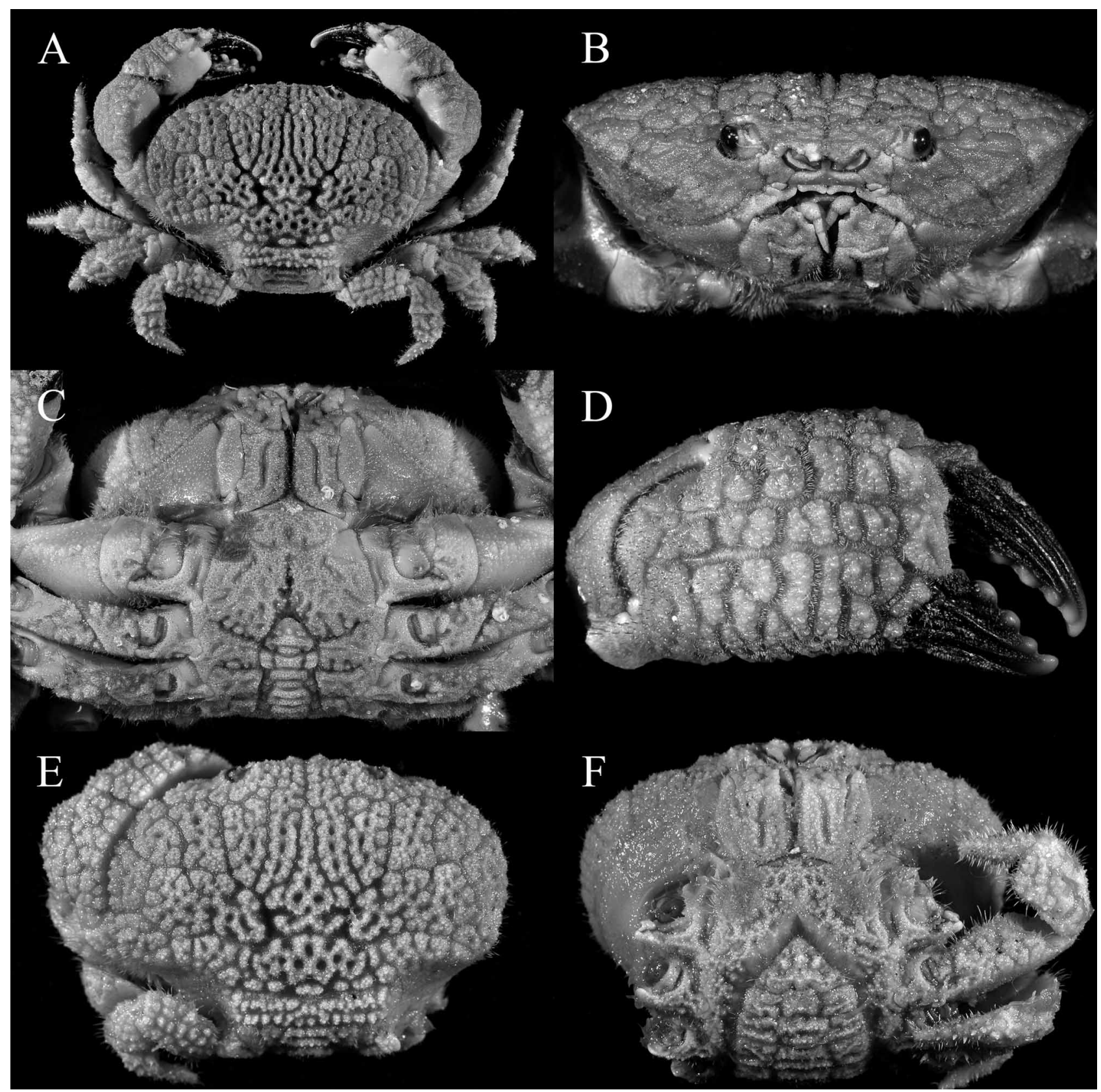

FIGURE 8. Glyptoxanthus meandricus (Lockington, 1877), A-D, neotype, male, $40.7 \times 27.1 \mathrm{~mm}$ (LACM CR 1940.65) Gulf of California: A, dorsal view; B, anterior view, C, ventral view; D, right chela, external view; E-F, female, $33.9 \times 23.0 \mathrm{~mm}$ (MNHN-B8362), Gulf of California: E, dorsal view; F, ventral view. 
Ecology and geographical distribution. Glyptoxanthus meandricus has only been found, thus far, in the Gulf of California, presumably from the intertidal to the shallow subtidal zones amidst rocky substrate.

\section{Glyptoxanthus meandrinus (Klunzinger, 1913)}

(Fig. 9A, B)

Actäa (Psaumis) mäandrina Klunzinger, 1913: 185 [89], pl. 1 fig. 5, pl. 6 fig. 4 (type locality: Kosseir, Red Sea).

Actaea vermiculata, Odhner 1925: 57, pl. 4 fig. 1. Not Cancer vermiculatus Lamarck, 1818.

?Glyptoxanthus meandrinus, Guinot 1971: 1073.

Glyptoxanthus meandrinus, Guinot 1967: 556; 1979: 68, pl. 6 fig. 7. —Serène 1984: 83.

Material examined. None. The only known specimen is the type, supposedly deposited in the Stuttgart Museum.

Diagnosis. (Modified from Klunzinger (1913)) Carapace transversely ovate, width-to-length ratio 1.5; regions more-or-less defined, intervening furrows wide, especially cervical furrow; $2 \mathrm{M}$ nearly completely divided except for fused anterior section with $1 \mathrm{M} ; 3 \mathrm{M}$ fused to inner branch of $2 \mathrm{M}$ posteriorly; $4 \mathrm{M}$ bridging $3 \mathrm{M}$ and $1 \mathrm{P} ; 2 \mathrm{~L}, 3 \mathrm{~L}$, 4L distinct, $5 \mathrm{~L}$ and $6 \mathrm{~L}$ fused, distinct oblongate cavity on 5L; 1P with 2 parallel, transverse furrows; $2 \mathrm{P} \mathrm{X}$-shaped, entire; vermiculations narrow, rough, anfractuous. Front quadrilobate. Anterolateral margins arcuate, divided into 4 distinct lobes, posterior 3 triangular, last acutely so. Male thoracic sternum regularly eroded, with near-symmetric pattern of cavities and ridges. External surfaces of pereopods with similar sculpturing as dorsal carapace. Abdomen with transverse bars. G1 and G2 unknown.

Remarks. Klunzinger (1913) described Actäa (Psaumis) mäandrina (= Actaea meandrina), from Kosseir (= Al-Qusair), on the Egyptian coast of the Red Sea, and from only one small specimen, "size: $6 \mathrm{~mm}$ ", of indeterminate sex. This species was considered by Odhner (1925) as a juvenile Actaea vermiculata (Lamarck, 1818), and he also cast some doubt as to the real provenance of Lamarck's types, which were supposedly from the Caribbean region. Guinot (1979), however, contradicted this and provided evidence that Glyptoxanthus vermiculatus can indeed be found in the Caribbean Sea. She further commented on the disjunct distributional pattern of G. vermiculatus and G. meandrinus, which strongly suggested that the two were distinct species. This opinion was also held by Serène (1984), who included G. meandrinus in his list of the crabs of the Red Sea and the western Indian Ocean. In the absence of additional specimens from the Red Sea, Glyptoxanthus meandrinus is also considered as distinct from G. vermiculatus in the present work. Although the holotype, deposited in the Stuttgart Museum (see Odhner 1925; Serène 1984), was not available for examination, the figures provided by Klunzinger (1913) and Odhner (1925) were sufficiently clear to make comparisons. Glyptoxanthus meandrinus differs from G. vermiculatus primarily by the narrower, simpler vermiculations and the wider grooves and furrows on the dorsal carapace surface (vermiculations thicker and more convoluted, and intervening furrows much narrower in G. vermiculatus), and by the presence of a distinct oblongate cavity on the 5L subregion (absent in G. vermiculatus).

Ecology and geographical distribution. Klunzinger (1913: 186 [90]) described the colouration of this species as "... white, including the fingers in their whole length" [translated]. It is known only from the type locality. Very little else is known about this rare species.

\section{Glyptoxanthus vermiculatus (Lamarck, 1818)}

(Figs. 9C-F, 10H)

Cancer vermiculatus Lamarck, 1818: 271 (type locality: most probably Caribbean Sea, see Guinot 1979: 66).

Xantho vermiculatus, H. Milne Edwards 1834: 391. —Desbonne in Desbonne \& Schramm 1867: 27. —A. Milne-Edwards 1868: 49.

Glyptoxanthus vermiculatus, A. Milne-Edwards 1879: 255, pl. 43 fig. 2. —Rathbun 1900: 288; 1930: 266, pl. 108 fig. 4, pl. 109. -Guinot 1971: 1073; 1979: 66, fig. 18F. —Tavares \& Albuquerque 1990: 67, fig. 2. —Melo 1996: 355, 1 fig. Cobo et al. 2002: 156, fig. 1D. —Almeida \& Coelho 2008: 202. —Ng et al. 2008: 199 (list).

?Glyptoxanthus vermiculatus, Guinot 1967: 556.

Material examined. Caribbean Sea: Lectotype, male, $41.8 \times 28.6 \mathrm{~mm}$, paralectotype, female, $34.2 \times 24.2 \mathrm{~mm}$ (MNHN-B3016), locality written as "? Floride" on label, no other data. 
Curaçao: 1 female, $32.3 \times 21.2 \mathrm{~mm}$ (USNM 7589), coll. Albatross, 10-18 Feb. 1884 .

Suriname: 1 male, $38.0 \times 25.4 \mathrm{~mm}(\mathrm{RMNH}-\mathrm{D} 12181)$, off the coast, between mouths of Coppename \& Suriname rivers, coll. Coquette, 19-22 Jul. 1957.

Diagnosis. Carapace transversely ovate, width-to-length ratio 1.4-1.5; carapace regions more-or-less defined, cervical furrow slightly wider than other furrows; $2 \mathrm{M}$ nearly completely divided longitudinally except anterior part which is fused with $1 \mathrm{M}$; posterior part of $3 \mathrm{M}$ fused to inner branch of $2 \mathrm{M} ; 4 \mathrm{M}$ bridging $3 \mathrm{M}$ and $1 \mathrm{P} ; 2 \mathrm{~L}, 3 \mathrm{~L}, 4 \mathrm{~L}$ distinct, $5 \mathrm{~L}$ and $6 \mathrm{~L}$ fused; $1 \mathrm{P}$ with 2 parallel transverse furrows; $2 \mathrm{P} \mathrm{X}$-shaped, somewhat subdivided into smaller lobules; vermiculations moderately thick, convoluted, generally smooth, with traces of fused granules. Front quadrilobate. Anterolateral margins arcuate, divided into 4 distinct, subtriangular lobes. Male thoracic sternum eroded, with near-symmetric pattern of ridges and cavities. External surfaces of pereopods with similar sculpturing as dorsal carapace surface. Abdomen with transverse bars. G1 long, slender, distal end studded with spiniform granules, apex blunt, aperture large, unobstructed, ventral margin with 2 short, simple setae; G2 one-fourth length of G1
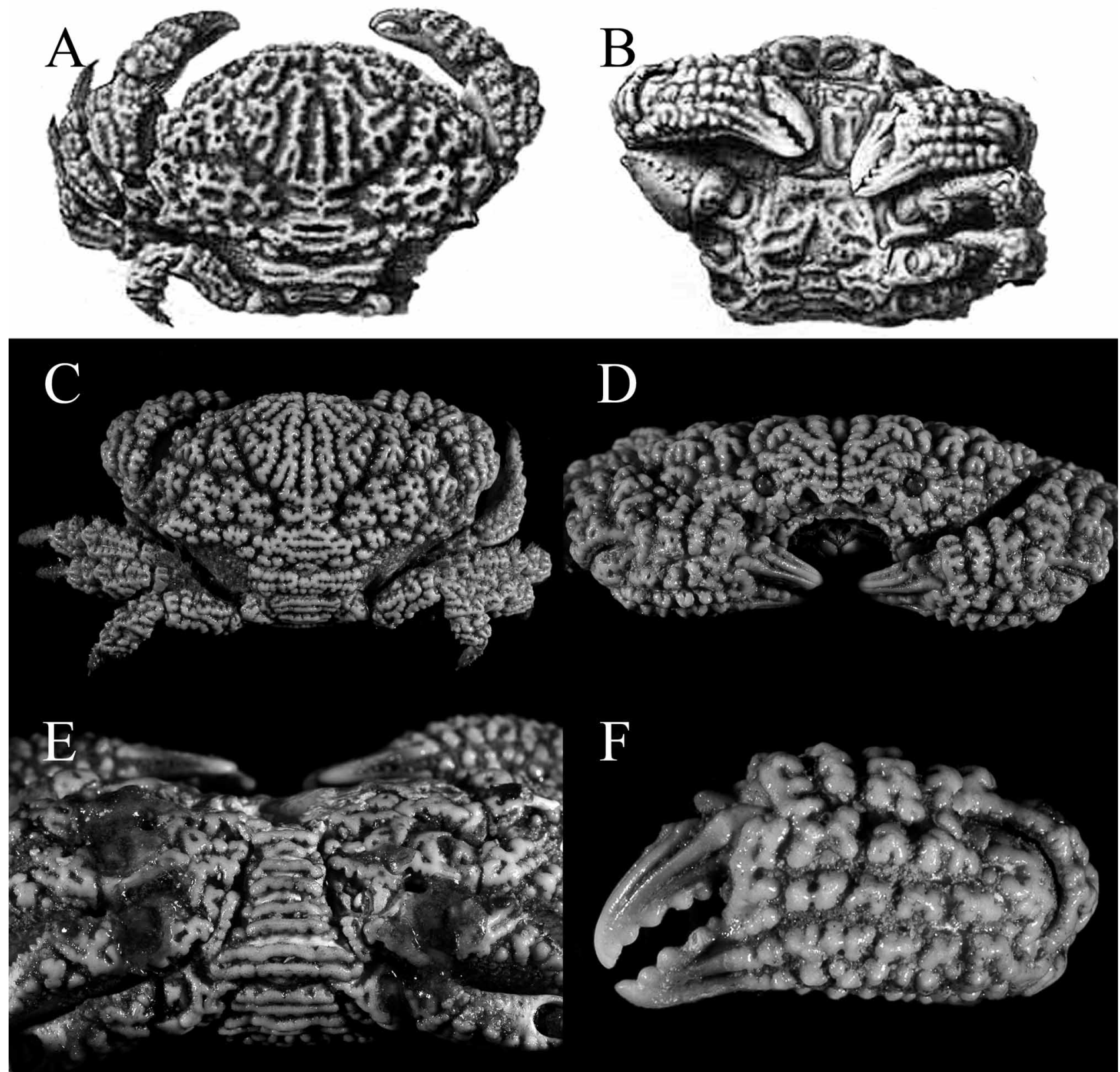

FIGURE 9. A-B, Glyptoxanthus meandrinus (Klunzinger, 1913), holotype, male, $9.0 \times 6.0 \mathrm{~mm}$ (Strasburg Museum), after Odhner (1925): A, dorsal view, B, ventral view. C-F, Glyptoxanthus vermiculatus (Lamarck, 1818), lectotype, male, $41.8 \times$ 28.6 mm (MNHN-B3016), Caribbean Sea: C, dorsal view, D, anterior view, E, posteroventral view, F, left chela, external view. 

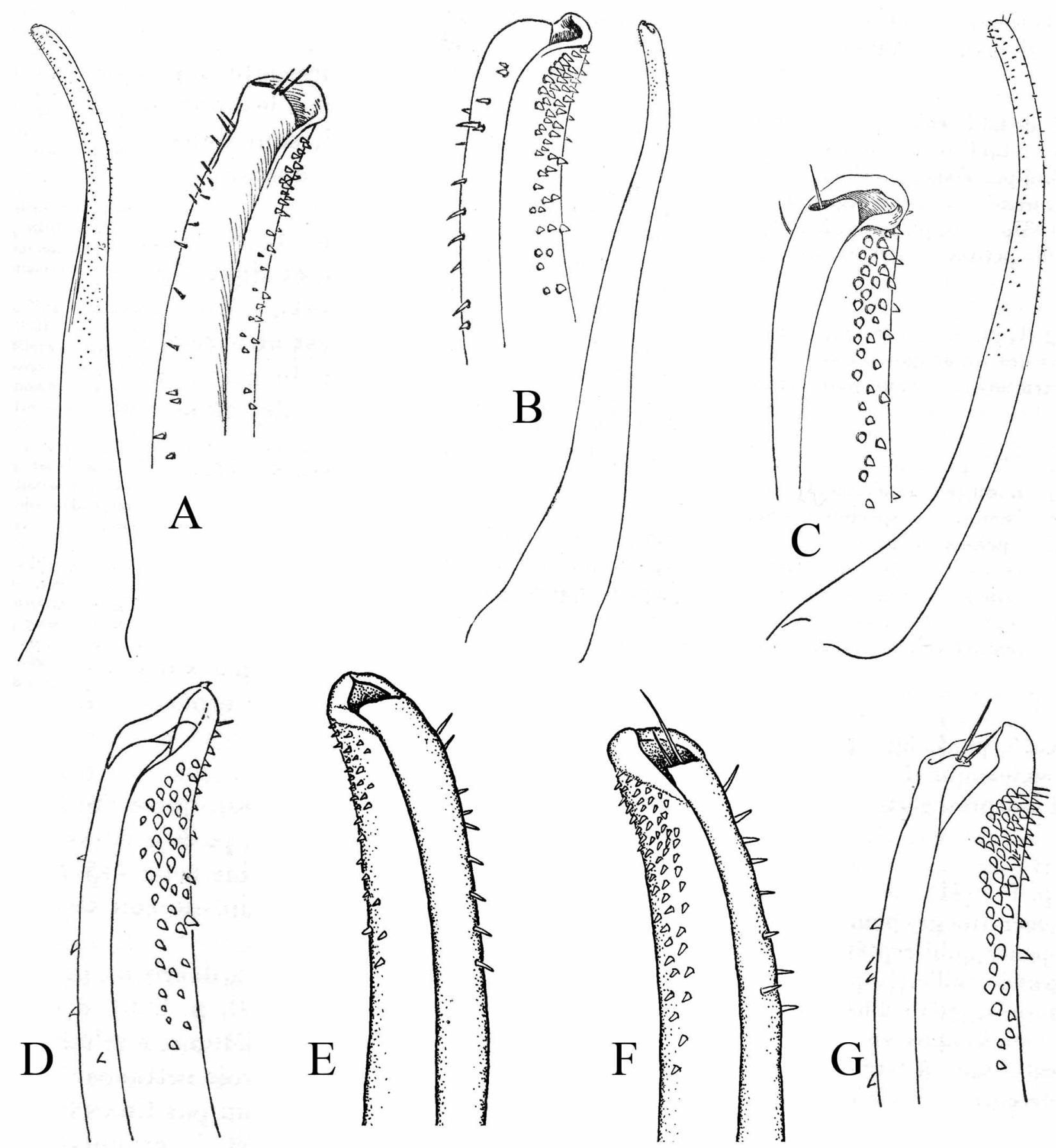

FIGURE 10. Glyptoxanthus spp. gonopods (G1). A, G. angolensis (Brito Capello, 1866); B, G. cavernosus (A. Milne-Edwards, 1878); C, G. erosus (Stimpson, 1859); E, G. corrosus (H. Mile Edwards, 1834); E, G. labyrinthicus (Stimpson, 1860), (LACM CR 1935.075.3); F, G. meandricus (Lockington, 1877), neotype (LACM CR 1940.65); G, G. vermiculatus (Lamarck, 1818). (A-C, D, G, after Guinot 1979).

Remarks. Lamarck (1818) described Cancer vermiculatus from two specimens purportedly collected from the "Antilles" (= Caribbean). Subsequently, other workers treated it as a species of Xantho, and reported additional specimens from the Caribbean region (H. Milne Edwards 1834; Desbonne, in Desbonne \& Schramm 1867; A. Milne-Edwards 1868). A. Milne-Edwards (1879) eventually established a new genus, Glyptoxanthus, to accommodate this and five other species. Some confusion had arisen from several reports of G. vermiculatus from outside the Caribbean (i.e., Cape Verde Islands, western coast of Africa, Red Sea) which were actually of different species of Glyptoxanthus, and/or from the poorly substantiated synonymization of related species (see previous Remarks for 
other Glyptoxanthus spp.; see also Osorio 1897, 1898, 1907; Odhner 1925; Rathbun 1930). Guinot (1977, 1979) stabilized the taxonomy of this species by selecting the male specimen (of the two syntypes originally studied by Lamarck) as the lectotype, and by highlighting the morphological distinctive characters. She expressed some doubt on the provenance of Lamarck's type specimens (which were said to have come from "? Floride", as written on the label), and went on to confirm the presence of this species in the Caribbean Sea based on her examination of specimens collected and reported by earlier workers from that region.

Glyptoxanthus vermiculatus is superficially similar in morphology to two Atlantic species, G. erosus from the western Atlantic including the Caribbean and the Gulf of Mexico, and G. angolensis from the eastern Atlantic, particularly in the general form and sculpturing of the carapace. However, G. vermiculatus can be distinguished from these two species primarily by the presence of two parallel furrows on the cardiac region (1P) of the carapace (several, separate, small cavities in G. erosus and G. angolensis). The G1s differ significantly among these species (Fig. 10; also Guinot 1979: fig. 18B, D, F). Furthermore, the condition of the gastric regions differs among the three species. In G. vermiculatus, $2 \mathrm{M}$ is almost completely divided longitudinally except for the fused anterior part, which also fused to $1 \mathrm{M}$; in G. erosus, the fusion occurs on the posterior part of $2 \mathrm{M}$, and in G. angolensis, $2 \mathrm{M}$ is not as clearly divided as either of the two species. Glyptoxanthus vermiculatus is morphologically most similar to $G$. meandrinus from the Red Sea, particularly in the way the $2 \mathrm{M}$ region is divided, in the presence of two parallel transverse furrows on $1 \mathrm{P}$, and in the pronounced subtriangular lobes on the carapace anterolateral margin. However, G. vermiculatus has thicker and more convoluted vermiculations, narrower intervening furrows, and no oblongate cavity on $5 \mathrm{~L}$; whereas $G$. meandrinus has narrower, less convoluted vermiculations coupled with wider furrows, as well as a clear oblongate cavity on $5 \mathrm{~L}$. There is some uncertainty as to whether G. vermiculatus and $G$. meandrinus are distinct species. In fact, Odhner (1925) considered the two to be conspecific, choosing to believe that the true type locality of G. vermiculatus was probably in the Indo-West Pacific rather than in the Caribbean. It is also possible that the small size of the holotype of G. meandrinus means that it is a juvenile, and, therefore, the observed differences in carapace morphology are age-related and intra-specific. In the absence of additional specimens from the Red Sea, however, and in light of the confirmed presence of G. vermiculatus in the Caribbean and the western Atlantic, we consider the two species to be distinct.

Ecology and geographical distribution. This species has been obtained at depths of approximately $10 \mathrm{~m}$, and has been observed to be associated with coral heads (Cobo et al. 2002). Thus far, there have been no reports of $G$. vermiculatus from Florida or anywhere north of the Caribbean region (e.g., Rathbun 1930; Williams 1965, 1984), although this species has been found on the South American coast as far south as southeastern Brazil (Melo 1996; Cobo et al. 2002; Almeida \& Coelho 2008). Therefore, we consider the northern limit of G. vermiculatus' range as within the Caribbean Sea, for the moment.

\section{Acknowledgements}

The authors would like to thank the following, for their kind and generous assistance during museum visits and facilitation of specimen loans: Régis Cleva (MNHN), Jody Martin, Regina Wetzer, Dean Pentcheff, and Kathy Omura (LACM), Lipke B. Holthuis, Charles Fransen, and Jacques Smit (RMNH), Rafael Lemaitre, Karen Reed, Chad Walter and the staff of the Department of Invertebrate Zoology (USNM), and Tan Swee Hee, Tan Siong Kiat, and Martin Low (ZRC, NUS). The authors also thank their colleagues in the EDIT 1 Xanthidae Project, Paul Clark, Peter Ng, and Joelle Lai, for generously sharing their data and for the fruitful discussions on xanthid systematics. Thanks are also due to Darren Yeo, Rudolf Meier, Paul Clark, Peter Ng and Peter Castro for their valuable comments and suggestions for the improvement of this paper. This study was supported by the National University of Singapore (ARF Grant \# R-154-000-334-112), and also in part by a Singapore-France Merlion travel grant and by the European Distributed Institute of Taxonomy (EDIT).

\section{References}

Abele, L.G. \& Kim, W. (1986) An Illustrated Guide to the Marine Decapod Crustaceans of Florida. Florida: Department of Environmental Regulation, Technical Series, Vol. 8, No. 1, Part 2, 760 pp.

Alcock, A. (1898) Materials for a carcinological fauna of India. No. 3. The Brachyura Cyclometopa. Part I. The family Xanthi- 
dae. Journal of the Asiatic Society of Bengal (Calcutta), 67(2), 67-233.

Almeida, A.O. \& Coelho, P.A. (2008) Estuarine and marine brachyuran crabs (Crustacea: Decapoda) from Bahia, Brazil: checklist and zoogeographical considerations. Latin American Journal of Aquatic Research, 36(2), 183-222.

Balss, H. (1921) Crustacea VI: Decapoda Anomura (Paguridae) und Brachyura (Dromiacea bis Brachygnatha). In: Michaelsen, W. (Ed.) Beiträge zur Kenntnis der Meeresfauna Westafrikas, III, Lief. 2, Hamburg. pp. 37-68.

Bouvier, E.L. (1922) Observations complémentaires sur les Crustacés Décapodes (abstraction fait des Carides) provenant des campagnes de S.A.S. le Prince de Monaco. In: Résultats Campagnes Scientifiques du Prince Albert de Monaco, fasc. LXII, 106 pp., 6 pls.

Brito Capello, F. de (1866, 1867) Descripção de algunas especies novas ou pouco conhecidas de Crustaceos e Arachnidios de Portugal e possessões portuguezas do ultramar. Lisbon, 17 p., 2 pls.

Capart, A. (1951) Crustacés Décapodes Brachyures. Expédition océanographique Belge dans les eaux côtières africaines de l'Atlantique Sud (1948-1949). Résultats Scientifiques, 3(1), 11-205.

Cobo, V.J., Pinheiro, A.P., Freire, F.A.M. \& Martins, I.A. (2002) Range extension of the geographic distribution of lobsters (Palinuroidea) and crabs (Xanthoidea) in the Brazilian coast. Nauplius, 10(2), 155-158.

Crane, J. (1937) Brachygnathous crabs from the Gulf of California. The Templeton Crocker Expedition. III. Zoologica (New York), 22(3), 47-78, pls. 1-8.

Dana, J.D. (1851) On the classification of the Cancroidea. American Journal of Science and Arts, 12(34), 121-131.

De Grave, S., Pentcheff, N.D., Ahyong, S.T., Chan, T.-Y., Crandall, K.A., Dworschak, P.C., Felder, D.L., Feldmann, R.M., Fransen, C.H.J.M., Goulding, L.Y.D., Lemaitre, R., Low, M.E.Y., Martin, J.W., Ng, P.K.L., Schweitzer, C.W.L., Tan, S.H., Tshudy, D. \& Wetzer, R. (2009) A classification of living and fossil genera of decapod crustaceans. Raffles Bulletin of Zoology, Suppl. No. 21, 1-109.

Desbonne, I. (1867) In: Desbonne, I. \& Schramm, A. Crustacés de la Guadeloupe d'après un manuscrit du Docteur Isis Desbonne comparé avec les échantillons de Crustacés de sa collection et les dernières publications de MM. Henri de Saussure et William Stimpson, Brachyures: i-ii, 1-60, pls. 1-8. (Imprimerie du Gouvernement, Basse Terre; édité par A. Schramm).

Felder, D.L. (1973) An annotated key to crabs and lobsters (Decapoda, Reptantia) from coastal waters of the northwestern Gulf of Mexico. Center for Wetland Resources. Baton Rouge: Louisiana State University. 103 p.

Forest, J. \& Guinot, D. (1966) Crustacés Décapodes: Brachyoures. In: Campagne de la Calypso dans le golfe de Guinée et aux îles Principe, São Tomé et Annobon (1956), 16. Annales de l'Institut Océanographique (Monaco), 44, $23-124$.

Garth, J.S. (1939) New brachyuran crabs from the Galapagos Islands. Allan Hancock Expeditions, 5(2), 9-49, pls. 1-10.

Garth, J.S. (1946) Littoral brachyuran fauna of the Galapagos Archipelago. Allan Hancock Pacific Expeditions, 5(10), i-iv, 341-600, pls. 49-87.

Gauld, D.T. (1960) Brachyura: An annotated check-list of the Crustacea of Ghana, IV. Journal of the West African Science Association, 6(1), 68-72.

Glassell, S.A. (1934) Affinities of the brachyuran fauna of the Gulf of California. Journal of the Washington Academy of Science, 24(7), 296-302.

Guinot, D. (1967) Recherches préliminaires sur les groupements naturels chez les Crustacés Décapodes Brachyoures. III. A propos des affinités des genre Dairoides Stebbing et Daira de Haan. Bulletin du Muséum national d'Histoire naurelle, $2^{\mathrm{e}}$ série, 39(3), 540-563.

Guinot, D. (1971) Recherches préliminaires sur les groupements naturels chez les Crustacés Décapodes Brachyoures. VIII. Synthèse et bibliographie. Bulletin du Muséum national d'Histoire naurelle, $2^{\mathrm{e}}$ série, 42(5), 1063-1090.

Guinot, D. (1979) Données nouvelles sur la morphologie, la phylogenèse et la taxonomie des Crustacés Décapodes Brachyoures. Mémoires du Muséum national d'Histoire naturelle (Paris), (A) Zoologie, 112, 1-354, pls. 1-27.

ICZN (1999) International Code of Zoological Nomenclature. Fourth Edition. International Commission of Zoological Nomenclature. Adopted by the $21^{\text {st }}$ General Assembly of the International Union of Biological Sciences. International Trust for Zoological Nomenclature, in association with the British Museum (Natural History), London. 338 pp.

Klunzinger, C.B. (1913) Die Rundkrabben (Cyclometopa) des Roten Meeres. Abhandlungen der kaiserlich Leop.-Carol. Deutschen Akademie der Naturforscher Halle 2, 97-402 [1-306], pls. 5-11 [1-7].

Lai, J.C.Y., Mendoza, J.C.E., Guinot, D., Ng, P.K.L. \& Clark, P.F. (in press) Xanthidae MacLeay, 1838 (Decapoda: Brachyura: Xanthoidea) systematics: A multi-gene approach with support from adult and larval morphology. Zoologischer Anzeiger.

Lamarck, J.B.P.A. (1818) Histoire naturelle des animaux sans vertèbres, présentant les caractères généraux et particuliers de ces animaux, leur distribution, leurs classes, leurs familles, leurs genres, et la citation des principales espèces qui s'y rapportent; précédée d'une introduction offrant la détermination des caractères essentiels de l'animal, sa distinction du végétal et des autres corps naturels, enfin, l'exposition des principes fondamentaux de la zoologie. Volume 5: 1-612.

Lockington, W.N. (1877) Remarks on the Crustacea of the west coast of North America, with a catalog of the species in the Museum of the California Academy of Sciences. Proceedings of the California Academy of Sciences, 7, 145-156.

Longhurst, A.R. (1958) An ecological survey of the West African marine benthos. Colonial Office, Fishery Publications, 11, 1102.

MacLeay, W.S. (1838) Illustrations of the Annulosa of South Africa; being a portion of the objects of natural history chiefly collected during an expedition into the interior of South Africa, under the direction of Dr. Andrew Smith, in the years 1834, 1835, and 1836; fitted out by the "Cape of Good Hope Association for Exploring Central Africa." In: Smith, A. (Ed.), Illustrations of the zoology of South Africa investigations. London: Smith, Elder and Co., pp. 1-75, pls. 1-4. 
Manning, R.B. \& Holthuis, L.B. (1981) West African brachyuran crabs (Crustacea: Decapoda). Smithsonian Contributions to Zoology, No. 306, i-xii, 1-379.

Melo, G.A.S. (1996) Manual de dentificação dos Brachyura (Caranguejos e Siris) do litoral brasileiro. Ed. Plêaide, São Paulo, $604 \mathrm{p}$.

Mendoza, J.C.E. \& Ng, P.K.L. (2008) New genera and species of euxanthine crabs (Crustacea: Decapoda: Brachyura: Xanthidae) from the Bohol Sea, the Philippines. Raffles Bulletin of Zoology, 56(2), 385-404.

Milne-Edwards, A. (1868) Observations sur la faune carcinologiques des îles du Cap-Vert. Nouvelles Archives du Muséum d'Histoire naturelle (Paris), 4, 49-68.

Milne-Edwards, A. (1869) Description de quelques espèces nouvelles de Crustacés provenant du voyage de M. A. Bouvier aux îles Cap Vert. Revue et Magasin de Zoologie Pure et Appliquée, (ser. 2) 21, 350-355.

Milne-Edwards, A. (1878) Description de quelques espèces nouvelles de Crustacés provenant du voyage aux îles Cap-Vert de MM. Bouvier et de Cessac. Bulletin de la Societé philomatique (Paris), (sér. 7), 2, 225-232.

Milne-Edwards, A. (1879) Etudes sur les Crustacés Podophthalmaires de la région mexicaine. In: Mission scientifique du Mexique, Recherches zoologiques pour servir à l'histoire de la faune de Amérique Centrale et du Mexique, (5) 1, 225-312, pls. 40-54.

Milne Edwards, H. (1834-1837) Histoire naturelle des Crustacés. Paris. I, 1834: i-xxxv + 1-468; II, 1837 : 1-532; Atlas, 1837: 1-37, pls. $1-42$.

Monod, T. (1933) Sur quelques Crustacés de l'Afrique occidentale (liste des Décapodes mauritaniens et des Xanthidés ouestafricains). Bulletin du Comité d'Études Historiques et Scientifiques de l'Afrique Occidentale Française, 15, 456-548.

Monod, T. (1956) Hippidea et Brachyura ouest-africaines. Mémoires de l'Institut Fondamental d'Afrique Noire, 45 , 1-674.

Ng, P.K.L., Guinot, D. \& Davie, P.J.F. (2008) Systema Brachyurorum: Part I. An annotated checklist of extant brachyuran crabs of the world. Raffles Bulletin of Zoology, Supplement No. 17, 1-286.

Odhner, T. (1925) Monographierte Gattungen der Krabben-familie Xanthidae. I. Göteborgs Kungliga Vetenskaps- och Vitterhets-Samhälles Handlingar, (4) 29(1), 1-92, figs. 1-7, pls. 1-5.

Osorio, B. (1887) Liste des Crustacés des possessions portugaises d'Afrique Occidentale dans les collections du Muséum d'Histoire naturelle de Lisbonne. Jornal de Sciencias mathematicas, physicas e naturaes (Lisboa), 11(47), 186-191.

Osorio, B. (1898) Da distribuição geographico dos Peixes e Crustaceos colhidos nas possessões portuguezas d'Africa occidental e existes no Museum Nacional de Lisboa. Jornal de Sciencias mathematicas, physicas e naturaes (Lisboa), ser. 2, 5(19), 185-202.

Osorio, B. (1906) Uma nova lista de Crustaceos Africanos. Jornal de Sciencias mathematicas, physicas e naturaes (Lisboa), ser. 2, 7(27), 149, 150.

Rathbun, M.J. (1897) A revision of the nomenclature of the Brachyura. Proceedings of the Biological Society of Washington, $11,153-167$.

Rathbun, M.J. (1898) The Brachyura collected by the United States Fish Commission steamer Albatross on the voyage from Norfolk, Virginia, to San Francisco, California, 1887-1888. Proceedings of the United States National Museum, 21, 567616, pls. 41-44.

Rathbun, M.J. (1900) The decapod crustaceans of West Africa. Proceedings of the United States National Museum, 22(1), 271361.

Rathbun, M.J. (1911) Marine Brachyura. In: The Percy Sladen Trust Expedition to the Indian Ocean in 1905 under the leadership of Mr. J. Stanley Gardiner. Vol. III. No. IX. Transactions of the Linnaean Society of London, Zoology, 14(2), 191-261, pls. $15-20$.

Rathbun, M.J. (1930) The cancroid crabs of America of the families Euryalidae, Portunidae, Atelecyclidae, Cancridae, and Xanthidae. Bulletin of the United States National Museum, 152, 1-609.

Rathbun, M.J. (1933) Descriptions of new species of crabs from the Gulf of California. Proceedings of the Biological Society of Washington 46, 147-150.

Serène, R. (1961) Les espèces indo-pacifiques d'Actea et celles des genres Pseudactea et Banareia $\left(1^{\mathrm{e}}\right.$ partie). Bulletin de la Société zoologique de France, 86(2-3), 195-212.

Serène, R. (1962) Les espèces Indo-Pacifiques d'Actea et celles des genres Pseudactea et Banareia (2 $2^{\mathrm{e}}$ partie). Bulletin de la Société zoologique de France, 86(6), 673-693, pl. 1.

Serène, R. (1968) The Brachyura of the Indo Pacific Region. In: Prodromus for a check list of the non-planctonic marine fauna of South East Asia. Special Publication of the Singapore National Academy of Science, No. 1. 33-120 pp.

Serène, R. (1984) Crustacés Décapodes Brachyoures de l'océan Indien occidental et de la mer Rouge. Xanthoidea: Xanthidae et Trapeziidae. Avec un addendum par A. Crosnier: Carpiliidae et Menippidae. Faune tropicale, 24, 1-400, Pls. 1-48.

Sourie, R. (1954) Contribution à l'étude écologique des côtes rocheuses du Sénégal. Mémoires de l'Institut Fondamental d'Afrique Noire, No. 38, 232 pp., 33 pls.

Stimpson, W. (1859) Notes on North American Crustacea, No. 1. Annals of the Lyceum of Natural History of New York, 7, 4993.

Stimpson, W. (1860) Notes on North American Crustacea, in the Museum of the Smithsonian Institution, No. II. Annals of the Lyceum of Natural History of New York, 7, 177-246, pls. 2, 5.

Stimpson, W. (1871) Preliminary report on the Crustacea dredged in the Gulf Stream in the Straits of Florida by L.F. de Pourtales, Assist. U. S. Coast Survey. Part I. Brachyura. Bulletin of the Museum of Comparative Zoology (Harvard), 2, 109- 
160.

Tavares, M.S. \& Albuquerque, E.F. (1990) Redescrição e ocorrência de Glyptoxanthus vermiculatus (Lamarck) (Crustacea: Brachyura: Xanthidae) no litoral brasileiro. Atlântica, 12(1), 67-71.

d'Udekem d'Acoz, C. (1999) Inventaire et distribution des Crustacés Décapodes de l'Atlantique nord-oriental, de la Méditerranée et des eaux continentales adjacentes au nord de $25^{\circ}$ N. Patrimonies Naturels (M.N.H.N./S.P.N.), 40, 1-383.

Ward, M. (1933) New genera and species of marine Decapoda Brachyura from the coasts of New South Wales and Queensland. Australian Zoologist, 7(5), 377-394, pls. 21-23.

Williams, A.B. (1965) Marine decapod crustaceans of the Carolinas. Fishery Bulletin of the Fish \& Wildlife Service (U.S.A.), 65(1), 1-298.

Williams, A.B. (1984) Shrimps, Lobsters, and Crabs of the Atlantic Coast of the Eastern United States, Maine to Florida. Washington, D.C.: Smithsonian Institution Press. 550 pp. 